\title{
RECLAIMING THE FIRST AMENDMENT THROUGH UNION DUES RESTRICTIONS?
}

\author{
Harry G. Hutchison*
}

\section{OVERVIEW}

\section{A. Introduction}

Conversations about compulsory financial contributions to labor unions ${ }^{1}$ and related abuses of union expenditures ${ }^{2}$ occupy a contestable space. Despite suffering from chronic obscurity, the debate has been electrifying. ${ }^{3}$ Dues objectors contend that compelled membership

* Professor of Law, George Mason University School of Law. For helpful comments on earlier drafts, I am grateful to Elizabeth McKay, Timothy Hartge, Nelson Lund and Ronald Rotunda. The usual disclaimer applies. Research support was generously provided by the Law \& Economics Center, George Mason University School of Law.

1. Section 8(a)(3) of the National Labor Relations Act (NLRA), "as interpreted and applied by the courts and the National Labor Relations Board ... does not require that employees become full union members subject to union rules and discipline. Rather . . employees can only be required to pay dues and initiation fees as a condition of employment." Ronald Turner, "Membership" Obligations Under NLRA Section 8(a)(3): A Proposal for Statutory Change, 17 HofsTRA LAB. \& EMP. L.J. 323, 325 (2000) (referencing 29 U.S.C. § 158(a)(3) (1994)). Similar rules apply to public employees covered by state law. See, e.g., Abood v. Detroit Bd. of Educ., 431 U.S. 209 (1977) (opining the U.S. Supreme Court found that the Constitution does not prevent an agency shop agreement between a public employer and an employees' union that requires every employee in the unit to pay a service fee to defray the costs of representation).

2. See, e.g., Robert P. Hunter, Paul S. Kersey \& Shawn P. Miller, The Michigan Union ACCOUNTABILITY ACT: A StEP TOWARD ACCOUNTABILITY and DEMOCRACY IN Labor Organization 10-13 (2001), available at The Mackinac Center for Public Policy, 140 West Main Street P.O. Box 568 Midland, Michigan 48640 (providing an example of union leaders embezzling union dues).

3. See, e.g., Jennifer Friesen, The Costs of "Fee Speech"-Restrictions on the Use of Union Dues to Fund New Organizing, 15 HASTINGS CoNST. L.Q. 603, 606 (1988) (providing a brief history of an argument against restricting the use of union dues); Roger C. Hartley, Constitutional Values and the Adjudication of Taft-Hartley Act Dues Objector Cases, 41 HASTINGS L.J. 1, 2 (1989) ("Dues objector litigation has been raging quietly in Railway Labor Act and public sector collective bargaining contexts for over thirty years."); Harry G. Hutchison, $A$ Clearing in the Forest: Infusing the Labor Union Dues Dispute with First Amendment Values, 14 WM. \& MARY BILL RTS. J. 1309 (2006) [hereinafter Hutchison, $A$ 
constitutes a cover for forcing ideological conformity ${ }^{4}$ and allege that both membership and financial contributions impermissibly interfere "with their freedom of thought, conscience and association protected by the Bill of Rights to the Federal Constitution." "Objectors typically challenge political, ideological, organizing and lobbying expenditures, and dispute union compliance with constitutional principles governing the collection and the rebate of fees. ${ }^{6}$ Such objections traverse the ostensible barrier between private and state action as well as the boundary cabined by the Railway Labor Act (RLA), National Labor Relations Act (NLRA), and state statutes governing public employee bargaining. ${ }^{7}$

The Supreme Court's recent decision, upholding a Washington state initiative that imposed paycheck protection restrictions on labor unions, ${ }^{8}$ is sure to rekindle this conversation. This debate will likely extend beyond pure legal analysis and the implications of the Court's often repeated admonition that a union "could not, consistently with the Constitution, collect from dissenting employees any sums for the support of ideological causes not germane to its duties as collective-bargaining agent." conversation will also transcend the perimeters of the employer-employee relationship and encroach on the boundary established by conflicting

Clearing in the Forest] (analyzing the union dues dispute from a free speech viewpoint); Harry G. Hutchison, Diversity, Tolerance and Human Rights: The Future of Labor Unions and the Union Dues Dispute, 49 WAYNE L. REV. 705 (2003) [hereinafter Hutchison, Diversity, Tolerance and Human Rights] (analyzing the union dues dispute from a human rights perspective); Harry G. Hutchison, Reclaiming the Union Movement Through Union Dues? A Postmodern Perspective in the Mirror of Public Choice Theory, 33 U. Mich. J.L. REFORM 447 (2000) [hereinafter Hutchison, Reclaiming the Union Movement Through Union Dues] (arguing that union dues subvert the interests of individuals in support of hierarchical claims); Heidi Marie Werntz, Waiver of Beck Rights and Resignation Rights: Infusing the Union-Member Relationship with Individualized Commitment, 43 CATH. U. L. REV. 159 (1993) (analyzing the effect of dues checkoffs on union members).

4. Lehnert v. Ferris Faculty Ass'n, 500 U.S. 507, 515 (1991) (citing Ry. Employes' Dep't v. Hanson, 351 U.S. 225, 238 (1956)).

5. Robert a. Gorman \& Matthew W. Finkin, Basic Text on labor law: UNIONIZATION AND COLLECTIVE BARGAINING 916 (2d ed. 2004).

6. Id. at $916-35$.

7. Id. at 916-27.

8. Davenport v. Wash. Educ. Ass'n, 127 S. Ct. 2372 (2007) (upholding $§ 760$, a state restriction, as applied to public-sector unions that restricts a union's authority to coerce financial payments for political purposes).

9. Ellis v. Railway Clerks, 466 U.S. 435, 447 (1984). See also Lehnert, 500 U.S. at 521 (holding that neither labor peace, nor the goal of avoiding free-riding, is served by charging objecting public employees for lobbying, electoral and other political activities that do not relate to their collective-bargaining agreement); Chicago Teachers Union v. Hudson, 475 U.S. 292, 293 (1986) (applying Ellis to public-sector union dues disputes). But see Commc'n Workers of Am. v. Beck, 487 U.S. 735, $739-43$ (1988) (upholding the dissenters' challenge to compulsory dues on duty of fair representation grounds but declining to reach the dissenters' First Amendment claim). 
interpretations of human autonomy, solidarity, the First Amendment and election campaign finance laws. Debates can either illuminate or produce confusion. Ultimately this debate addresses the proper role of labor unions in a representative democracy. ${ }^{10}$ Sorting through this dispute is made more difficult because Americans live in a society, if not a world, that appears to be falling apart." Accordingly, squabbles about human autonomy, the necessity of group cooperation, the role of unions and the scope of constitutional mandates are apt to become hazy no matter how much revelation becomes available.

One commentator asserts that the Davenport decision, requiring the teachers' unions to get nonmembers' permission before expending their dues for political purposes, represents a setback for organized labor. ${ }^{12}$ Another observer heralds the decision as a vindication of First Amendment rights of nonunion members to be free from compulsory payments for a union's political speech. ${ }^{13}$ By contrast, Bob Chanin, general counsel for the National Education Association (NEA), America's largest teacher's union, downplays the ruling as having no practical effect on labor unions. ${ }^{14}$ Bradley Smith, former chairman of the Federal Election Commission (FEC), offers the most nuanced response. ${ }^{15} \mathrm{He}$ contends that paycheck protection laws rarely live up to the hype because such laws are generally written under the auspices of campaign finance, and therefore only affect a tiny sliver of union political expenditures: express advocacy. ${ }^{16}$ Moreover, state campaign finance laws do not apply to federal election activity. ${ }^{17}$ Hence, the impact of state paycheck protection initiatives, like the one at issue before the Davenport Court, appears to be negligible. ${ }^{18}$ The irrelevancy of such initiatives multiplies due to the information asymmetry between objectors and union officials. The latter ${ }^{19}$ can easily evade the

10. Hutchison, Reclaiming the Union Movement Through Union Dues, supra note 3, at 448-49 (discussing two possible conceptions of labor unions).

11. Frederick Mark Gedicks, Spirituality, Fundamentalism, Liberty: Religion at the End of Modernity, 54 DEPAUL L. REV. 1197, 1197 (2005).

12. David G. Savage, Justices Curb Unions' Use of Fees for Politics, L.A. TIMES, June 15,2007 , at $\mathrm{A} 20$.

13. Brad Shannon, High Court Rejects 'Opt Out,' Olymplan, June 14, 2007, at 1B (quoting Washington State Attorney General Rob McKenna).

14. Amy Fagan, States Can Put Rules on Use of Union Fees, WASH. Times, June 15, 2007, at A01 (quoting Bob Chanin).

15. Bradley A. Smith, A Free-Speech Salve; End Compulsory Unionism, WASH. TIMES, June 29, 2007, at A19 (arguing against government regulation of political speech).

16. $I d$.

17. Id. Federal campaign-finance debates may be affected by the Supreme Court's decision upholding a challenge to the Bipartisan Campaign Reform Act ("BCRA") of 2002. Fed. Election Comm'n v. Wis. Right to Life, Inc., No. 06-969, slip op. at 3 (June 25, 2007) (permitting certain issue ads to be aired during BCRA blackout periods).

18. Smith, supra note 15.

19. Hutchison, A Clearing in the Forest, supra note 3, at 1395-98. 
intent of these laws by slightly modifying the nature of their political expenditures. ${ }^{20}$ In fact, creative accounting evidently allowed labor unions to collect and spend substantially more money on politics (broadly defined) the year after the Washington state law went into effect. ${ }^{21}$ In consideration of the above, the capability of union dues restrictions to protect the preferences and the interests of working people from the threat of ideological conformity remains in doubt. My thesis is that the Supreme Court's holding in the Davenport case cannot fully vindicate human autonomy or individual liberty despite the claims and counter-claims of a number of observers. Correctly understood, this decision promises little and delivers even less because it fails to deal decisively and comprehensively with the issues that both earlier private sector ${ }^{22}$ and public sector $^{23}$ union dues disputes illuminated but failed to settle. Tied to the earlier precedent, the Davenport case falls short of recapturing fully the First Amendment values of expression and association.

\section{B. Background}

Leo Troy foreshadows the Davenport case and similar union dues litigation. We live, he argues, in an epoch that has experienced the decline in the "old unionism" and the rise in the "new unionism." 24 This development signifies the collapse of private-sector unions and the rise of public sector unions. ${ }^{25}$ The ascent of the "new unionism" signals the growing dominance of the labor movement by white-collar organizations including teachers' unions. ${ }^{26}$ Public sector unions appear to be committed to what can be described as an anti-market ideology. ${ }^{27}$ Anti-market ideology conduces toward pseudo-scientific and bureaucratic

20. Mark Mix, Supreme Court's Davenport Case Could Create Union Dues Rebate, EXAMINER, Dec. 15, 2006, http://www.examiner.com/printa-457701 Mark_Mix:_Supreme_ Court's_Davenport_case-could_create_union_dues_rebate.html; see also Hutchison, $\bar{A}$ Clearing in the Forest, supra note 3 , at $1395-1400$ (emphasizing accounting and other issues, which impair union dues objectors' ability to fully vindicate their rights).

21. Smith, supra note 15.

22. See, e.g., Commc'n Workers of Am. v. Beck, 487 U.S. 735 (1988) (discussing whether the collection of nonmembers' fees for purposes unrelated to collective bargaining violated the union's duty of fair representation); see also infra Part III.B-C. (discussing the legal precedent concerning first amendment rights in union dues adjudication).

23. See, e.g., Lehnert v. Ferris Faculty Ass'n, 500 U.S. 507 (1991) (discussing the limitations upon the payment of dues by a nonmember to a union in the public sector required as a condition of employment); see also infra Part III.B-C.

24. Richard W. Hurd, Industrial Relations Theory, 58 InDUS. \& LAB. REL. REV. 305, 305 (2005) (reviewing Leo TROY, THE TWILIGHT OF THE OLd UNIONISM (2004)).

25. Id. (citing TROY, supra note 24).

26. $I d$.

27. $I d$. 
managerialism, which is reflected in government efforts to manipulate the economy. ${ }^{28}$ This maneuver is legitimized by speculation that the government possesses resources that rank and file workers and citizens lack. ${ }^{29}$ Unions' anti-market attitude, justified presumably by the prospect of market failure, ignores the even greater likelihood of government failure. Anti-market/pro-bureaucracy ideology seems firmly attached to the fatal tendency of mankind to promote group welfare at others' expense by deploying the government to seize the earnings of others. ${ }^{30}$ It is far from clear that all workers have capitulated to this ideology no matter how frequently union leaders suggest otherwise. Wielding substantial economic wealth, ${ }^{31}$ unions continue to exert considerable political influence. ${ }^{32}$ It is possible that the political influence of public and private sector unions assures their long-term survival and the survival of the labor movement. ${ }^{33}$ Consistent with this thesis, Leo Troy identifies the Democratic Party as America's labor party through which unions have traditionally lobbied for their interests. ${ }^{34}$

As I have intimated elsewhere, ${ }^{35}$ Americans occupy a society that is waiting, but does not know what it is waiting for. ${ }^{36}$ Dreaming of liberation, ${ }^{37}$ individuals populate a variety of interest groups. American

28. Alasdair Macintyre, After Virtue: A Study in Moral Theory 85 ( $2 \mathrm{~d}$ ed. 1984). MacIntyre suggests that as the government becomes more scientific and accepts that it can manipulate human action, it "becomes a hierarchy of bureaucratic managers . . . ." Id. According to MacIntyre, "the major justification advanced for the intervention of government in society is the contention that government has resources of competence which most citizens do not possess." Id.

29. Id.

30. FRederic Bastiat, The LAW 9-10 (Dean Russell trans., 1990).

31. Hurd, supra note 24, at 305 (citing TROY, supra note 24); see also LINDA CHAVEZ \& DANIEL GRAY, BETRAYAL 12 (2004) (suggesting that labor union revenues approach or exceed upwards of $\$ 17$ billion a year).

32. See ChAVEZ \& GRAY, supra note 31 , at 12 (arguing that unions have so much money at their disposal that they can spend more on politics than do both major political parties combined); see also William J. Moore et al., The Political Influence of Unions and Corporations on COPE Votes in the U.S. Senate, 1979-1988, 16 J. LAB. RES. 203, 218-19 (1995) (concluding that the evidence fails to show a decline in the political influence of unions).

33. Hurd, supra note 24 , at 305 (citing TROY, supra note 24).

34. Id; see also CHAVEZ \& GRAY, supra note 31 , at 52-55 (explaining that John Sweeney, President of the AFL-CIO, led an effort by labor movement advocates to pour hundreds of millions of dollars in a campaign to support the Democratic Party's policies); Taylor E. Dark, The Unions and the Democrats: An Enduring Alliance (1999) (describing the strong relationship between the Democratic party and labor unions).

35. See generally Hutchison, A Clearing in the Forest, supra note 3, at 1311-14 (discussing the reasons behind Americans' declining interest in joining unions).

36. Chantal Delsol, ICarus Fallen: The Search for Meaning in an Uncertain WORLD Xxvii (2003).

37. Id. 
individualism may reflect the cultural climax of fourteenth and fifteenth century developments that emphasized a tradition of individual rights and liberties. ${ }^{38}$ In our contemporary society, citizens may surmise that choice enables them to find meaning in a life that confronts never-ending possibilities. ${ }^{39}$ In view of these humanistic attitudes, any evaluation of union dues and their appropriation in the political sphere raises questions about the nature of autonomy, individual as opposed to group motivation, and uncertainty about the goals that unions, like other groups, ought to pursue. ${ }^{40}$ This development has become part of a microcosm that mimics the clash of civilizations and cultures in the wider world. ${ }^{41}$ Self-interest, preferences, the boundaries of consent, and the benefits and costs of collective action are arrayed against the possibility that a broad definition of unions' societal function requires limiting individual rights and choices. $^{42}$ Such issues fuse politics, economics and First Amendment norms. ${ }^{43}$ These issues become ever more poignant as the labor movement struggles to stem decades of decline and combat the emerging fissures within the union hierarchy itself. ${ }^{44}$

Labor unions arose in part out of a moving critique of industrial capitalism and represent "the attempt to have the democracy of Paris without the slavery of Rome." ${ }^{\prime 45}$ The labor movement may reflect the "determination to assert the superiority of moral principles over economic appetites, which have their place . . in the human scheme, but which, like other natural appetites, when flattened and pampered and overfed, bring ruin to the soul and confusion to society. ${ }^{\$ 4}$ However moving labor's critique of the market may be, differences of opinion surface over the capability of labor unions to proffer moral principles sufficient to accomplishing the task of justifying their proposed solutions to society's ills.

Operationally, labor unions might function in either of two ways: (1) as a form of majoritarian hegemony that operates as statutorily privileged

38. Samuel P. Huntington, The Clash of Civilizations and the Remaking of WORLD ORDER 71 (1996).

39. Hutchison, A Clearing in the Forest, supra note 3, at 1311.

40. Id.

41. See, e.g., HUNTINGTON, supra note 38 , at 56-121.

42. George Feldman, Unions, Solidarity, and Class: The Limits of Liberal Labor Law, 15 BERKELEY J. EMP. \& LAB. L. 187, 193 (1994).

43. Hutchison, $A$ Clearing in the Forest, supra note 3, at 1311.

44. Thomas B. Edsall, Two Top Unions Split from AFL-CIO, WASH. POST, July 26, 2005 , at Al (noting the decline in the labor movement coupled with the resignation of two of the nation's largest unions from the AFL-CIO).

45. Richard Gill, Oikos and Logos: Chesterton's Vision of Distributism, 10 LoGOS 64, 65 (2007) (quoting Chesterton's interpretation of the labor problem).

46. Id. at 66-67 (quoting Richard Tawney in his analysis of moral values over economic growth). 
"mini-legislatures"47 or, alternatively, (2) as a group "to which the individual has given uncoerced express or tacit consent." $"$ Without individual assent, it is improbable that the group performs consistently with customary explanations of the First Amendment's freedom of association and free speech discourse. ${ }^{49}$ Since "any form of affiliation or association can impinge [on] ... individual sovereignty," human association may be viewed as "essentially artificial, instrumental and temporary in character" and an invasion of one's liberty. ${ }^{51}$ By one account, human autonomy can be attached securely to the substance and structures of constitutional democracy. ${ }^{52}$

Freedom of thought, conscience, speech, and association all appear to be attached to some conception of autonomy. ${ }^{53}$ The notion of autonomy is diminished, however, by its own set of difficulties. Autonomy can be stated in putatively neutral terms, but lurking behind allegiance to the idea of autonomy are faith commitments that not everyone shares. ${ }^{54}$ It is doubtful that radical human autonomy has been fully purchased by all workers and all Americans. Still, Americans possess diverse viewpoints on a wide range of issues which may animate their desire for First Amendment protection, including the protection of speech and association. Conversely, Stanley Fish vitiates such sentiments by arguing that for modern liberal societies like the United States, "there is no such thing as free speech," which he suggests is a good thing. ${ }^{55}$ This contradicts what has come to be

47. See Molly S. McUsic \& Michael Selmi, Post Modern Unions: Identity Politics in the Workplace, 82 IOWA L. REV. 1339, 1343 (1997) (suggesting that collective bargaining was conceived as a form of democratic self-government complete with general legislative principles including majority rule).

48. But see Thomas C. Kohler, Setting the Conditions for Self-Rule: Unions, Associations, Our First Amendment Discourse and the Problem of Debartolo, 1990 WIS. L. REV. 149, 183 (1990) (explaining that only those groups to which individuals consent have legitimate power).

49. Id. at 182-86 (arguing that the language that informs our first amendment discourse has taught us to regard freedom in individualistic terms).

50. Id. at 184 (explaining that associations are artificial, temporary and instrumental structures as they invade individual autonomy).

51. Id. (suggesting that entering into associations entails the surrender of some ability to freely make decisions).

52. See Youngjae Lee, Valuing Autonomy, 75 Fordham L. Rev. 2973, 2973-74 (2007) (discussing, through a review of James Fleming's book Securing Constitutional Democracy, the importance tied to both autonomy and freedom to make choices about self-governance, such as entering into associations).

53. Id. at 2974 (explaining that the right to make choices individually and as part of a group is part of one concept of liberty).

54. See Hutchison, Diversity, Tolerance and Human Rights, supra note 3, at 752 (suggesting that autonomy is not a neutral term).

55. See Larry Alexander, Is There a Right of Freedom of EXPression? 178 (2005) (quoting STANLey Fish, There's No Such Thing as Free SpeECH, AND IT'S A GoOd THING, 
seen as the classically liberal view; but perhaps some commentators and a few union hierarchs might agree with Professor Fish's intuition. Prowling in the background of most American debates are conflicting conceptions of liberalism. It is unlikely that labor union members and labor leaders have been able to resolve their conflicting views of liberalism on terms that all will agree are just.

Recent evidence confirms that private sector union membership is collapsing ${ }^{56}$ while public sector membership either stagnates or, more likely, declines. ${ }^{57}$ Though individual autonomy and liberty exist as contestable notions, ${ }^{58}$ it is plausible that atomistic autonomy and the principled commitment to liberty embodied in classically liberal notions of freedom of expression and association constitute a challenge to both private and public sector union growth as well as dominant conceptions of workers' collective interest. Resistance can take two forms: (1) a refusal to join unions, which fuels the ongoing decline in overall membership or (2) a refusal to pay dues by nonmembers who are represented by unions. Consistent with that paradigm, when Washington state public sector workers were given a choice of whether to support a labor union's political and ideological mission, nearly $85 \%$ refused to allow their dues go to politics. ${ }^{59}$ This case provides an additional example of the ongoing conflict between individual and group interests and between individual and group preferences.

This Article represents an extension of my prior work that has considered the union dues controversy. Since unions appear to be the locus of a postmodern conflict, Part II provides an analysis animated by public choice, postmodernism and First Amendment norms that underscore the complexity of the issues at stake. Part III offers an examination of

Too (1994) to argue that freedom of speech in part exists due to exercise of constraints on freedom of speech and other qualities that violate liberal understandings of it).

56. See, e.g., Barry T. Hirsch \& David A. Macpherson, Union Membership and Coverage Database from the CPS, http://www.trinity.edu/bhirsch/unionstats/contents.htm (last visited Feb. 28, 2008) (showing that private sector membership fell from $24.2 \%$ in 1973 to $7.4 \%$ in 2006 ).

57. Id. (showing that public sector membership fell from $38.7 \%$ in 1994 to $36.2 \%$ in 2006 while the percentage of covered workers fell from $44.7 \%$ to $40.1 \%$ during the same period).

58. See, e.g., Planned Parenthood of Southeastern Pennsylvania v. Casey, 505 U.S. 833, 851 (1992) (suggesting that "matters involving the most intimate and personal choices a person may make in a lifetime, choices central to personal dignity and autonomy, are central to the liberty protected by the Fourteenth Amendment."). But see J. BUDZISZEWSKI, WHAT WE CAN'T NOT KNOW 6-7 (2003) (offering a cautionary clarification of human autonomy).

59. See CHAVEZ \& GRAY, supra note 31 , at 46 (illustrating that individuals belonging to labor unions in the public sector do not want their labor unions to enter into the political arena; rather, they prefer to make politically-related choices individually while allowing unions to make ideologically-based choices). 
Supreme Court precedent, explores the ostensible distinction between private- and public-sector cases and inspects the validity of the Court's free-rider jurisprudence. The cases imply that First Amendment values appear to be highly contingent and court interpretations highly flexible. Part IV provides an examination of the Davenport case aimed at discovering Court deference, if any, to First Amendment rights and values. In Part V, I provide arguments, recommendations and speculations aimed at reclaiming human autonomy, individual liberty and a principled understanding of First Amendment ideals. Ultimately, however, I suggest the implausibility of recapturing a principled understanding of the First Amendment in a society torn apart by simmering disagreement. While the Supreme Court rightly enforced Washington State's dues restrictions, it is unlikely that paycheck protection legislation or referenda can rescue First Amendment rights and values from adjudication that transforms principle into a wobbly platform.

\section{LABOR UNIONS AS THE LOCUS OF POSTMODERN CONFLICTS?}

As a result of their political influence, revenues, and ideological commitments, labor unions have become the focal point of many contestable issues. Labor unions and labor federations, led by hierarchs, have taken sides in a variety of debates regarding contested policies. It is unlikely that all such decisions can be seen to epitomize collective rationality in some meaningful sense, particularly in the absence of worker preference uniformity. In view of the fact that labor unions and labor advocates increasingly see unions and the labor movement as a fighting force for class-based justice ${ }^{60}$ and societal transformation, it is possible that virtually all union expenditures (including collective-bargaining expenses) have freedom of expression implications that are adverse to the interests of dissenters.

To repeat a forecast that has now become a reality, the labor movement faces a period of serious retrenchment. Private-sector union density rates have fallen from $24.2 \%$ in 1973 to $7.4 \%$ in $2006 .{ }^{61}$ During the same period, public-sector rates rose from $23 \%$ to $36.2 \%{ }^{62}$ Today, even public-sector rates are not immune from decline, falling from $38.7 \%$ in 1994 to $36.2 \%$ in $2006 .{ }^{63}$ In addition, public-sector workers covered by

60. See id. at 52 (quoting Dennis Rivera, a New York City labor leader who supports a socialist agenda that includes class consciousness, social upheaval and the political rejuvenation of labor).

61. Hirsch \& Macpherson, supra note 56 (providing private-sector membership data)

62. Id.

63. Id. 
union contracts fell from $44.7 \%$ in 1994 to $40.1 \%$ during the same period. ${ }^{64}$ Overall union density (combined public and private sector rates) reflects this downward trend falling from $15.5 \%$ in $1994^{65}$ to approximately $12.5 \%$ in $2005^{66}$

The fall in union density rates appears to signify "that collective bargaining has become an anachronistic means of promoting employee interests" and may lead to the "loss of legitimacy for unions as the enablers of group action." 67 This phenomenon may confirm James Madison's suggestion that the diversity in the faculties of men is an obstacle to finding an enduring basis for uniformity of interest. ${ }^{68}$ Given the degeneration in union power and influence in the workplace, a variety of proposals for prolabor union action have arisen ${ }^{69}$ including the redeployment of union dues as a vehicle for reclaiming the labor movement. ${ }^{70}$ If union leaders see union dues principally as a vehicle for societal transformation, it would be remarkable if they did not attempt to compel labor solidarity through opposition to paycheck protection referenda, and legislation and adjudications that vindicate the claims of dissenters. At the same time, some hierarchs and labor advocates are drawn toward renewed efforts to revitalize collectivization ${ }^{71}$ through politics and an emphasis on labor organizing funded by dues contributions. ${ }^{72}$ These moves may be related and may pit workers' individuality against the supremacy of collective action, including efforts deemed necessary to achieve workplace

64. Id. (providing public-sector membership data).

65. Terry Thomason \& John F. Burton, Unionization Trends and Labor-Management Cooperation in the Public Sector, in GoIng Public: THE Role of LABOR-MANagement Relations in Delivering Quality Government Services 69, 72 (Jonathan Brock \& David B. Lipsky eds., 2003) (illustrating employment, union membership and union density).

66. Press Release, Alliance for Worker Freedom, Union Membership Plummets Across All Sectors of Workforce (Jan. 25, 2007), www.atr.org/content/pdf/2007/jan/012507awfprdensity.pdf (citing Bureau of Labor statistics).

67. James J. Brudney, Reflections on Group Action and the Law of the Workplace, 74 TEX. L. REV. 1563, 1564 (1996).

68. THE FEDERALIST No. 10, at 78 (James Madison) (Clinton Rossiter ed., 1961).

69. See generally Hutchison, Reclaiming the Union Movement Through Union Dues, supra note 3, at 455-56 (examining proposals for the enlargement of workplace democracy, increased access to the property of unorganized firms, the democratization of firms through a systematic program of egalitarian market reconstruction [government regulation], and boosting the minimum wage).

70. Id.

71. Ellen Dannin, NLRA Values, Labor Values, American Values, 26 BERKELEY J. EMP. \& LAB. L. 223, 274 (2005) (supporting collective values).

72. See, e.g., Friesen, supra note 3, at 603-04 (supporting the use of dues for organizing purposes). 
democracy, ${ }^{73}$ boosting the minimum wage or other labor reform agenda proposals.

None of these efforts are surprising. After all, labor unions, like other interest groups, come into being to further the interest of their members. ${ }^{74}$ But once the large initial costs of organization are overcome, unions tend to engage in other activities of interest to their members, or leadership, such as lobbying for legislation. ${ }^{75}$

Invoking echoes of the past, contemporary labor advocates appear intent upon spurring social improvement through greater government control of the economy. ${ }^{76}$ Not satisfied solely with government intervention in the economy, labor unions have taken positions on a number of issues unrelated to bargaining. Evidence can be adduced showing that unions have enlisted compulsory dues payments in support of drug legalization, campaigns to promote abortion, and efforts to compel the Boy Scouts to accept atheists and homosexuals. ${ }^{77}$ Although it is possible that the hierarchs possess insights and superior knowledge that workers lack, it would be remarkable if all rank and file workers agreed to disregard their own views on such topics to support the views of hierarchs. Whatever opinion workers may have regarding these controversies, it is difficult to imagine that labor union support for these causes improves workers' pay, benefits, or working conditions. ${ }^{78}$ It seems clear that unions are no longer captivated by such narrow issues as workers' pay and benefits but instead see themselves as a robust engine of collective insurgency that transcends the boundaries of craft, geography, the national-state and narrowly prescribed self-interests. ${ }^{79}$ This move encourages unions and union leaders to take controversial stances on a wide-range of issues that remain outside the frontier of workers' economic interest.

For several "decades after the founding of the labor movement, union leaders had eschewed politics because they recognized that their members did not all share the same political beliefs." ${ }^{~} 80$ Today, mounting viewpoint diversity among citizens and workers appears to be contradicted by the apparent willingness of union leaders to throw their members' interests to the wind in order to advance their own political beliefs. ${ }^{81}$ It is possible that

73. Karl E. Klare, Workplace Democracy \& Market Reconstruction: An Agenda for Legal Reform, 38 CATH. U. L. REV. 1, 3-7 (1988).

74. Dennis C. Mueller, Public Choice II 308 (rev. ed. 1989).

75. $I d$.

76. Chavez \& Gray, supra note 31 , at 16 .

77. Id. at 18 .

78. Id.

79. Hutchison, Reclaiming the Union Movement Through Union Dues, supra note 3, at 448-50.

80. Chavez \& GRAY, supra note 31 , at 18-19.

81. Id. at 19. 
these differences of opinion on controversial topics within the membership pivoted against labor hierarchs who use union dues to lobby for non-work related issues. These differences spur union fragmentation and undermine group solidarity. It is equally possible that some union leaders appear to have adopted an ossified conception of tolerance that instructs rank and file members to subordinate their own views and consciences to the superiority of the collective conscience. As part of this move, union hierarchs paper over deeply antagonistic world-views that mirror Alasdair MacIntyre's observation that there is an interminable and unsettleable character of much of what passes for American's contemporary moral and philosophical debates. ${ }^{82}$ The ever-increasing scope of these debates and the profound depth of cultural division combine to reflect a clash of orthodoxies on a number of levels. ${ }^{83}$

Against such maneuvers, postmodern norms and discourse add weight and poignancy to the allegation that workers' conflicting preferences and interests have been impermissibly suppressed. In the past, workers were seen to be bound together by their common interests, and whatever conflicts existed among workers paled in importance to the larger struggle against management. ${ }^{84}$ Today, the focal point of struggle has plausibly shifted to the diverse interests of workers. ${ }^{85}$ Consistent with this move, Professor Gedicks offers an invigorating hypothesis: instead of living in a society characterized by a uniformity of views, we live in a world that has fallen apart. ${ }^{86}$ We have been described variously as living at the end of an age, stalking the twilight of being, and muddling through the aftermath of confusion and helplessness in a world that lacks reality. ${ }^{87}$ This metaphysical implosion ${ }^{88}$ has a bearing on all of life, including the lives and the political aspirations of American workers, particularly when arrayed against contrasting hegemonic possibilities offered by union leaders. Whether Professor Gedicks is correct or incorrect, the dispute about the meaning, propriety and justification of labor union dues extracted for political purposes implies the difficulty of resolution on terms that all will concede as fair.

Coherent with this intuition, Professor MacIntyre contends:

82. MACINTYRE, supra note 28 , at 226.

83. See generally Robert P. George, The Clash of Orthodoxies: Law, Religion, AND MORALITY IN CRISIS (2001); Harry G. Hutchison, Shaming Kindergarteners? Channeling Dred Scott? Freedom of Expression Rights in Public Schools, 56 CATH. U. L. REV. 361, 361-68 (2007) [hereinafter Hutchison, Freedom of Expression Rights in Public Schools].

84. McUsic \& Selmi, supra note 47, at 1339.

85. Id.

86. Gedicks, supra note 11 , at 1197.

87. Id. at 1197-98.

88. Id. at 1197 . 
It is not just that we live too much by a variety and multiplicity of fragmented concepts; it is that these are used at one and the same time to express rival and incompatible social ideals and policies and to furnish us with a pluralist political rhetoric whose function is to conceal the depth of our conflicts. ${ }^{89}$

Explicating the incompatibility of Rawls and Nozick, Alasdair MacIntyre shows that it is probable that society can only move toward a shared understanding of justice within the context of a tradition and a community whose primary bond is a shared understanding of the good for man and for community where individuals identify their primary interest with reference to those goods. ${ }^{90}$ If MacIntyre's observations are true, postmodernism implicates contradictory understandings of justice, which verify that America and American workers face insoluble issues. Nor is government likely to be helpful in resolving these disputes. Government no longer represents a shared moral community of citizens but a set of institutional arrangements for imposing bureaucratized unity on a society that lacks a consensus. ${ }^{91}$

While collective agreement and cooperation may remain a faint possibility, labor unions must still confront the irresolvable character of debates over the morality of many political and social issues, including the basis for utilizing union dues for political and ideological purposes. For some commentators, union dues advance social and workplace "justice." For others, justice is impossible in the face of compelled expenditures that facilitate political and ideological goals. Such disputes, fastened as they are to alternative and incommensurable notions of justice, may not be settled short of authoritarianism or oblivion despite society's frequent resort to the language of pluralism, democracy and equality. This vocabulary serves to mask the depth and extent of Americans' disagreement and confirms Karl Marx's observation that "conflict and not consensus is at the heart of modern social structure." ${ }^{\prime 2}$

Disputes fester about what labor groups can legitimately demand of represented workers. Indeed, disagreement, not unanimity, may be the null hypothesis. ${ }^{93}$ Disagreements intensify because survey evidence focusing on private-sector workers implies that it is improbable that all or even a majority of workers share the conviction that conventional unions are the best vehicles for the advancement of the full gamut of their interests. ${ }^{94}$ If

89. MACINTYRE, supra note 28 , at 253.

90. Id. at 250 .

91. Id. at 254.

92. See, e.g., id. at 253 (illustrating the prevalence of conflict in the modern social structure).

93. Hutchison, $A$ Clearing in the Forest, supra note 3 , at 1313.

94. Samuel Estreicher, The Dunlop Report and the Future of Labor Law Reform, 12 LAB. LAW 117, 118 n.2 (1996). 
this data can be extrapolated to the entire workforce, it implies that the majority of unionized workers may be required to acquiesce to union mandates, even when they believe union hierarchs are deeply wrong. This conclusion is consistent with the recognition of public choice theory that individual interest has always been distinct from group interest. ${ }^{95}$ Coherent with this recognition, the salaries of union hierarchs continue to spiral upward while the number of union members and the pay and benefits for represented workers fall. ${ }^{96}$ Compulsory unions operating as a coercive grouping of people are likely to experience results that differ substantially from voluntary groups. Compulsion in contemporary America tends to repel rather than attract. However, given the complexities of diversity and identity, compulsion, for some unionists, may be the only option left to counter fragmentation.

Unions, like all other institutions, face the omnipresent possibility of capture by self-interested leaders or others. Capture may benefit the ideological predispositions of union leaders or outsiders with whom the leadership has formed a political or ideological bond. ${ }^{97}$ For instance, consistent with the actions of other labor hierarchs, John Sweeney, the current president of America's largest public and private sector labor federation, has tied the interests and the future of working people to the Democratic Socialists of America (DSA) ${ }^{98}$ revolution, ${ }^{99}$ defending the filibuster of judicial nominees, ${ }^{100}$ enhancing child support payments, ${ }^{101}$

By an overwhelming $86 \%$ to $9 \%$ margin, workers want an organization run jointly by employers and management, rather than an independent, employeerun organization. By a smaller, but still sizable margin of $52 \%$ to $34 \%$, workers want an organization to be staffed and funded by the company, rather than independently through employee contributions.

Id. at $n .2$ (quoting Richard FREEMAN \& JOEL ROGERS, WORKER REPRESENTATION AND Participation SurVey: RePORT ON THE Findings 49 (1994)).

95. Hutchison, A Clearing in the Forest, supra note 3, at 1314.

96. Mike Wilkinson \& Ron French, Labor Bosses Don't Share Workers' Pain-In Tough Time, Leaders Still Gain as Workers Lose Ground, DETROIT NEWS, Aug. 14, 2007, http://www.detnews.com/apps/pbcs.dll/article?AID=/20070814/BIZ/708140392\&imw=Y

(explaining that while workers have seen their health care and pension benefits gutted and wages frozen, union leaders are likely to keep their jobs and get raises and thus contribute to a widening pay gap between union members and leaders).

97. See, e.g., Hutchison, A Clearing in the Forest, supra note 3, at 1382-83 (discussing the capture of group resources for the purpose of achieving largely private benefits).

98. ChAvez \& GRAY, supra note 31 , at 19.

99. Id. at 20 (asserting that the DSA, with its ties to the Progressive Caucus of the Democratic Party, has apparently suggested a revolution complete with killing the bourgeoisie with guns and knives).

100. See United Food and Clerical Workers Union (UFCW), Legislative \& Political Action Meeting Index, available at http://www.ufcw.org/worker_political_agenda/2005_leg_and_pol_action_mtg/index.cfm.

101. Hutchison, $A$ Clearing in the Forest, supra note 3, at 1382. 
class-consciousness and social upheaval, ${ }^{102}$ and other causes, ${ }^{103}$ that appear to yield few benefits for working people. Evidently, labor unions plan to accomplish these goals by spending a larger percentage of members' dues on the political education of members. ${ }^{104}$ Achieving the necessary social and political changes that society requires includes, but is not limited to, the transformation of the members into instruments of the union hierarchs' agendas. This transmutation of traditional labor unions, duly understood as part of "Michel's Iron Law of Oligarchy," "105 yields self-interested benefits for some people, including union leaders and others who happen to share such opinions. ${ }^{106}$ These developments manifest themselves as yet another version of group-specific "rent-seeking behavior."107 These maneuvers also imply that the "hard left" has taken over public-sector, if not private-sector unions, and increased the likelihood that the public interest and the interest of rank and file workers have become permanently subordinated to special interest. ${ }^{108}$

In order to fully comprehend the prospect of capture, one must note that human self-interest ${ }^{109}$ can be found outside the confines of avaricious greed or monetary self-interest, and therefore, there is a wide array of explanations for the choices people make. ${ }^{110}$ A richer appreciation of selfinterest explains human behavior, including the possibility of group capture by hierarchs and ideologues. Capture surfaces as hierarchs impose their

102. Chavez \& GRAY, supra note 31 , at 52 .

103. Other causes apparently supported by union hierarchs include opposing a balanced budget and supporting a freeze on nuclear weapons. $I d$. at 18 .

104. Id. at 52.

105. Stewart J. Schwab, Union Raids, Union Democracy, and the Market for Union Control, 1992 U. ILL. L. REv. 367, 370 (1992).

106. These outsiders include individuals who are not represented by the union. See, e.g., Hutchison, $A$ Clearing in the Forest, supra note 3, at 1381-84 (discussing how the outsiders can get specific benefits).

107. Id. at 1383.

108. ChAVEZ \& GRAY, supra note 31 , at 16-23.

109. MUELLER, supra note 74, at 1 (suggesting that politics and economics have been typically divided "by the types of questions they ask, the assumptions they make about individual motivation, and the methodologies they employ."). Political science has presumed that politicians pursue the public interest. Id. "Economics has assumed that all men pursue their private interest." Id. This dichotomy can no longer be seen as valid.

110. Jeffrey Friedman, Introduction to The Rational ChOice CONTROVERSY 1, 20-21 (Jeffrey Friedman ed.,1996) (discussing instrumental rationality and its limits as well as alternative views on how human choice is formed); see also AMARTYA SEN, ON ETHICS \& ECONOMICS 10-28 (1987) (suggesting rationality can be variously viewed as consistency, as part of some self-interest determination, and as part of Adam Smith's understanding which, taken together under Sen's analysis, implies that rationality must include more than narrow self-interest in some purely pecuniary sense). But see DANIEL A. Farber \& PHILIP P. FRICKEY, LAW AND PUBLIC CHOICE: A CRITICAL INTRODUCTION 7 (1991) (suggesting that self-interest simply means avaricious greed in a simple monetary sense and thus implying that self-interest can be separated from ideological and nonmaterial considerations). 
individual preferences, provoking dissent and conflict within the unit. In the contemporary world, self-interest is tied to the full panoply of goods which include ideological, political and collective goods. ${ }^{111}$ It is, therefore, unsurprising that labor union hierarchs lend union support and financial resources to activities that promote abortion, foment opposition to welfare reform, ${ }^{112}$ contest "three strikes and you're out" initiatives, and support marijuana decriminalization. ${ }^{113}$ Compounding this development, labor unions appear to have succumbed to dominance by elite interest. ${ }^{14}$ This contention operates consistently with the observation that "[m]odern thought is much more elitist than ancient thought, though it talks a less elitist line." 115 This maneuver improves the odds that unions have metamorphosed into bureaucratic instruments that serve largely private and elite interests, as opposed to either the public interest, or the disparate interests of the rank and file. From Dennis Mueller's analysis, we can conclude that the incentives for the elites to engage in dominance and capture increase "[w]here the benefits from collective action are not the same across all group members." If If that is the case, "there is a systematic tendency for exploitation of the great by the small." 117 Thus even union majorities are not safe from exploitation.

If hierarchs decline to consider the disparate and conflicting conceptions of human autonomy present in contemporary society, and refrain from comprehending the variety of heterogeneous concepts that inform the major premises from which the protagonists of debates argue, it may cause difficulties. These difficulties, coupled with a refusal to adhere to First Amendment norms, may combine to forecast that labor federations and labor movements will be led by officials who insist on authoritarian domination instead of democracy. This surfaces as a probability because "[e]ven staunch union supporters blanche over the autocracy, entrenchment, and corruption of some union leaders." 118 But even if majoritarian union democracy exists, majoritarianism places at risk a robust

111. See, e.g., Gary S. Becker, A Theory of Competition Among Pressure Groups for Political Influence, 98 Q. J. OF ECON. 371, 372 (1983) (describing self-interested ways of exerting political pressure).

112. See, e.g., ChAVEZ \& GRAY, supra note 31 , at 18.

113. Id.

114. Terry Eagleton, The Idea of Culture 77 (2000) (stating that in an earlier time the international and largely western labor movement spoke to the masses, but that today it speaks to the elites); see also Hutchison, A Clearing in the Forest, supra note 3, at 1343 (suggesting that if solidarity implies "the way of life of a particular people living together in one place," as T.S. Elliot contends, unions and union leaders may no longer inhabit the same place as rank and file payers of union dues).

115. BUDZISZEWSKI, supra note 58, at 164.

116. MUELLER, supra note 74 , at 309.

117. Id.

118. Schwab, supra note 105 , at 368 . 
conception of diversity by offering instead a kind of shallow homogeneity that supplants a richer, deeper, but more antagonistic diversity that appears to be inescapably embedded in human life. ${ }^{119}$

Unionization dominated by elite interest and led by hierarchs may result in manipulation that generates a disparity in benefits. This movement reinforces the conclusion that contemporary unions are epitomized by an absence of a shared understanding of the purpose and place of workers in our society. Taken together, this model predicts that mounting conflicts between workers and union hierarchs are inevitable. Conflict is likely to intensify when compulsory union dues are seized and placed into the service of politics and when (and if) the policy-related benefits flow disproportionately to union leaders and their ideological brethren. This paradigm comes alive with the dynamic specter of forcedriding that requires rank and file members to shoulder the financial burden necessary to obtain certain special interest ${ }^{120}$ or collective goods ${ }^{121}$ while reaping few, if any, benefits.

In the face of inevitable conflict, American society and some workers have become captivated by postmodern viewpoints. Alternatively, many workers remain animated by a principled conception of liberty of conscience grounded in Bastiat's conception of the law. ${ }^{122}$ If First Amendment norms defensibly protect viewpoint diversity, conflicting labor union meta-narratives ${ }^{123}$ are placed at risk. Previously, labor movement stories had the tenuous capacity to hold the workforce together. Today, such stories face the possibility of escalating incredulity. ${ }^{124}$ Although group cooperation and solidarity may have been possible in a modern

119. ALEXANDER, supra note 55 , at 170 (explaining how modern liberalism as cosmopolitanism shallows out true diversity).

120. Special interest goods may provide excludable or non-excludable benefits to the special interest group, but even if the benefits are not fully excludable, the benefits flow disproportionately to some members of the group. See, e.g., P.A. MCNUTT, THE ECONOMICS OF PUBlic ChOICE 180 (1996) (discussing how the benefits flow disproportionately to a minority of the group).

121. Id. at 178 (discussing that although collective goods tend to provide nonexcludable benefits, since they are provided through the political process, the benefits may flow disproportionately to the sponsors of the collective goods).

122. See, e.g., BASTIAT, supra note 30, at 6-7 ("Life, liberty and property do not exist because men have made laws. On the contrary, it was the fact that life, liberty and property existed beforehand that caused men to make laws in the first place. . . . Thus since an individual cannot lawfully use force against the person, liberty, or property of another individual, then the common force [government] - for the same reason-cannot lawfully be used to destroy the person, liberty or property of individuals or groups.").

123. Gedicks, supra note 11, at 1198 (relating postmodernism to general accounts of human history independent of other contextual influences like culture and location).

124. See, e.g., McUsic \& Selmi, supra note 47, at 1339-41 (explaining why women, minorities and others have difficulty accepting the subversion of their own interest to the presumed larger interest of unions' traditional constituencies). 
world committed to Enlightenment myths, the advent of postmodernism marks both the end of modernity and a break with most, or all, universal myths, ${ }^{125}$ including the myth of the universal worker. ${ }^{126}$ This move provides language which makes it feasible to question the notion and possibility of human progress. It also supplies a foundation from which to challenge unionism's putatively progressive impulses.

Unquestionably, postmodern implications, and even postmodernism itself, ought to be embraced with caution rather than enthusiasm because the deficiencies in postmodern implications may impair postmodernism's ability to reclaim liberty and First Amendment values. In fact, it may be difficult to define First Amendment values through postmodern discourse. Some, but not all, postmodern individuals might be accurately described as uncommitted, restless, ever-open, conversion prone, and "therefore congenitally ready to be converted and reconverted ad nauseam-without the conviction that would stop the dizzying spin and allow them to be at home somewhere."127 Postmodern individuals of the more serious variety may be influenced by Simone Weil's insight. She writes: "We possess nothing in this world other than the power to say I." ${ }^{28}$ Then again, a postmodern thinker might be captivated by the Nietzchean self-mastery and the will to power. ${ }^{129}$ Other postmodern individuals may be consumed by the grand pursuit of identity construction that is based on ethnicity, gender, or in a purely suburban move, the body. ${ }^{130}$ This particular approach may crumple into an enduring fascination with cookbooks and health foods. ${ }^{131}$ This approach also gives rise to the question of whether we postmodern individuals, or modern thinkers of any and all varieties, have the purpose to match our techniques. This is because the near-omnipotence, or presumed omnipotence, of our means of freedom may double back to join hands with the apparent emptiness of our ends. ${ }^{132}$ Postmodernism, then, raises more questions than it can possibly answer. ${ }^{133}$ Equally likely, postmodern

125. Gedicks, supra note 11 , at 1199 (linking the end of universal myths, like that of Enlightenment, and the demise of modernity with the beginning of postmodernism).

126. McUsic \& Selmi, supra note 47, at 1341 (discussing the possible subversion of varieties of human identity to the purported interest of the "universal worker").

127. Os Guinness, The Call: Finding and Fulfilling the Central Purpose of Your LIFE 10 (2003)

128. Id. at 18 .

129. Id. at 22 .

130. Id.

131. Id.

132. Id.

133. Normatively, one may not necessarily be persuaded by the fluent individualism of postmodernism because its anti-foundationalism may merely denote the contemporary manifestation of Sophism. BUDZISZEWSKI, supra note 58, at 167. Correctly understood, this new form of Sophism appears to deny reality, while resisting any notion of truth that endeavors to make sense out of life. Id. In addition, the complete acceptance of 
thought gives rise to other critical concerns that limit the viability, if not the coherence of postmodern discourse. ${ }^{134}$

Nonetheless, workers increasingly enticed by "expressive individualism," which focuses on subjective self-realization, are less likely to find attractive any collective action that requires individual interests to yield to group interest and group solidarity. ${ }^{135}$ This diminishes the demand for unionism and collectivization and emphasizes the notion that each individual has the right to decide the proper ends of her life. ${ }^{136}$ This attitude reinforces workers' First Amendment interest in establishing referenda, legislation and adjudication that endeavor to eliminate labor union's authority to extract funds from dissenters. At the same time dissent expands. Postmodern analysis signals that unions have always represented a diverse group of workers-a fact that has been often overlooked. Labor unions have ignored traditional, yet pervasive, sources of diversity including: religion, ethnicity, gender, politics and ideology. Additionally, labor unions appear to have disregarded the necessity and urgency of the modern search for the purpose of life. Sociologist Os Guinness illustrates this search as follows:

The question his own life-purpose, is what drove the Danish thinker Soren Kierkegaard in the nineteenth century. As he realized well, personal purpose is not a matter of philosophy or theory. It is not purely objective, and it is not inherited like a legacy. Many a scientist has an encyclopedic knowledge of the world, many a philosopher can survey vast systems of thought, many a theologian can unpack the profundities of religion, and many a journalist can seemingly speak on any topic raised. But all that is theory and, without a sense of personal purpose, vanity. ${ }^{137}$

Postmodernism can exists in two senses. Postmodern thought can surface in an aspirational or a descriptive sense. Postmodern thought can also

postmodernist claims reifies particularism and its complete rejection of universalist claims. EAGLETON, supra note 114 , at 76 . This move has the potential to completely sever the individual from society. Hutchison, A Clearing in the Forest, supra note 3, at 1338.

134. Postmodern scholars contend that there is no such thing as truth. See, e.g., Richard RORTY, CONTINGENCY, IRONY AND SOLIDARITY 5 (1989). If Rorty's postmodern claim is correct, then contemporary man may be left without the means to identify the good. Therefore, he will remain ignorant of how the evil he identifies has come about, even though his intuition tells him he is seeing evil. DeLSOL, supra note 36, at 52. If we are in fact able to identify absolute evil in the world, that forces us to believe that an order exists beyond our will, and beyond our capacity as creators of order, thus placing into issue the subjective morality of our time. Id. at 53 .

135. Hutchison, Reclaiming the Union Movement Through Union Dues, supra note 3, at 453.

136. $I d$.

137. OS GUINNESS, supra note 127 , at 3. 
emerge in an authoritarian impulse that demands that government power be employed to enforce, rather than to recognize the existence and implications of identity and difference. To the extent that postmodern claims are grounded in mandatory and normative demands for enforceable recognition, it may lead a government to alter the terms of civil association in ways that will neither resolve problems nor bring about social harmony. ${ }^{138}$ For purposes of this Article, I have attempted to understand postmodernism in its former, as opposed to latter, sense.

This Article concentrates largely on free speech issues, but it seems clear that both coerced agency fees, like speech, and accompanying coerced association have the capacity to intrude on the integrity of individual identity and intellectual individualism, even if courts are inclined to limit such intrusions. ${ }^{139}$ Litigation in this arena concentrates on whether unions should be able to extract and expend funds when the challenged expenditures violate a person's liberty interests. Adjudication turns on the constitutional values that are implicated by the challenged expenditure. ${ }^{140}$ Postmodernism may reinforce this controversy by providing additional analytical intensity that allows the depth of difference, disagreement and conflict within American society and its workers to surface.

\section{DISCOVERING CORE FIRST AMENDMENT RIGHTS IN UNION DUES ADJUDICATION?}

\section{A. Grounds for Skepticism}

Observers ought to be cautious about embracing the Supreme Court's First Amendment jurisprudence for many reasons. The Supreme Court did not actively protect the freedom of speech and expression until the end of the first quarter of the twentieth century. ${ }^{141}$ For much of the twentieth century the Court was unclear regarding the standards to be used in this arena. ${ }^{142}$ Only during the last third of the twentieth century did the Court develop its basic framework for regulating governmental restrictions on

138. Chandran Kukathas, The Fraternal Conceit: Individualist versus COLLECTIVIST IDEAS OF COMMUNITY 2 (1991) (on file with author).

139. Leora Harpaz, Justice Jackson's Flag Salute Legacy: The Supreme Court Struggles to Protect Intellectual Individualism, 64 TEX. L. REV. 817, 865-66 (1986) (discussing employee reaction to forced association with unions in workplaces that have unions, even if the dissident does not believe in the union's actions).

140. Hartley, supra note 3 , at $82-83$. In faimess to Hartley, he is primarily concerned with challenged expenditures premised on ideological grounds within the private sector. Id.

141. John E. NOWAK \& Ronald D. Rotunda, Constitutional Law 1130 (7th ed. 2004).

142. Id. 
expressive activity. ${ }^{143}$ Although the Supreme Court has suggested that the state cannot compel union members, or workers who are represented by a union, to make contributions for political purposes unrelated to collective bargaining, ${ }^{144}$ the Court's freedom of speech decisions continue to provide as much ground for skepticism as philosophers' claims that rights can be understood as universal. For example, dissenters recently challenged a government program that required certain farm producers to subsidize an advertising campaign promoting generic goods. ${ }^{145}$ The Supreme Court acknowledged a free speech right not to be compelled to contribute to an organization whose expressive activities conflict with one's freedom of belief. Nevertheless, the Court upheld the program on grounds that such assessments are germane to the regulatory program and because a program that requires objectors to pay such assessments cannot be said to engender any crisis of conscience. ${ }^{146}$ The Court's modern moral claim hints at three possibilities: (1) that some background principle can be invoked to avoid invalidating a particular government program, (2) that the courts have the capacity to know and adequate resources to explain what provokes a crisis of conscience, and (3) that First Amendment adjudication is highly flexible. Interestingly, this is not the first time the Court has invoked moral principles to decide the scope of an individual's liberty interests. In a leading equal protection case, Planned Parenthood of Southeastern Pennsylvania v. Casey, ${ }^{147}$ the Court appeared equally willing to ground its decision in moral principle as opposed to social compromise. But then, in what appears to have been a postmodern move, the Court assured us that it was not bound by the plain meaning of its own words. ${ }^{148}$ Instead, responding to contemporary political and social pressures, which it had pledged to disavow, the Court offered compromise and flexibility instead of principle. This move appears to be mandated by the Court's desire to avoid invalidating prior precedent ${ }^{149}$ and perhaps by its desire to validate its own version of cosmopolitan liberalism and self-evident truth. ${ }^{150}$ Equally

143. Id.

144. Id. at 1163 .

145. Id. at 1162 .

146. Id at 1162-63 (citing Glickman v. Wileman Bros. \& Elliott, Inc., 521 U.S. 457 (1997)).

147. Planned Parenthood of Southeastem Pennsylvania v. Casey, 505 U.S. 833 (1992) (holding the provisions restricting women were unconstitutional).

148. Id at 865-66 (focusing on legal principles to overrule previous cases); see also Hutchison, Freedom of Expression Rights in Public Schools, supra note 83, at 391 (discussing how the Court reasoned that it was basing its decision in Casey on principle and not on political pressures or compromises).

149. Casey, 505 U.S. at 867 (recognizing the presence of political pressure, yet noting that the Court is not swayed only by political pressure).

150. For a discussion of this possibility, see Nelson Lund \& John O. McGinnis, Lawrence v. Texas and Judicial Hubris, 102 MICH. L. REv. 1555, 1558-60 (2004). 
possible, all union dues contributions, including those collected for collective bargaining purposes may engender a moral crisis for dissenters. ${ }^{151}$ However, courts haunted by the omnipresent specter of compromise may be poised to vitiate the interest of dues objectors regardless of how principled their dissent may be.

It is far from clear whether the Supreme Court possesses adequate moral, philosophical and legal resources to clarify how the constitutive components of a cognizable crisis of conscience are implicated within the various debates about agriculture, abortion, or even union dues. Moral principles as deployed by the Court appear to be rather elastic, available for use when needed and absent from analysis when required. This validates Christopher Shannon's intuition that "[f]or most of the modern era, morality has been invoked as an alternative to nihilism. In our present postmodern moment, morality has revealed itself to be nihilism."152 This provocative claim is complemented by the allegation that rights are an inherently Western invention that are simply made up and constructed by a certain historical culture. ${ }^{153}$ This also suggests some difficulty in discovering sturdy universal moral principles to guide the courts. The Court may have been captivated by language that renders the invocation of morality and rights as nothing more than nihilism that has refashioned itself as part of the cost of muddling through. ${ }^{154}$ If such sentiments are correct, all court opinions risk skepticism no matter how much we agree with the judgment.

\section{B. Legal Precedent}

Retreating from skepticism in favor of conventional analysis for the moment, the union dues controversy has provided precedent for future courts to consider. Contemporary adjudication makes manifest that "private and public sector workers who are not union members may be obliged to pay 'agency fees' to recognized labor unions as a condition of employment when and if the union-management contract requires such

151. See, e.g., Harpaz, supra note 139, at 865-66 (exploring the moral claims of dissenters who assert all unwanted association violates their freedom of association).

152. Christopher Shannon, Conspicuous Criticism: Tradition, the individual, AND Culture IN MODERN AMERICAN SOCIAL ThOUght 198 (rev. ed. 2006) (arguing that there is no morality in American society).

153. William A. EDMundson, AN Introduction to Rights 3 (2004) (discussing whether rights are universal or just a Western construct).

154. ALEXANDER, supra note 55, at 185-93 (noting that the process of muddling through with respect to freedom of expression claims in a liberal society represents "practices that have a rule-consequentialist structure of justification specific to particular kinds of questions and to particular cultures, eras, and technologies"). 
payments."15s The Supreme Court first considered a challenge to compulsory union dues in $1956^{156}$ where it upheld the RLA as a valid enactment of Congress under the commerce power designed to ensure stability in the railroad industry. ${ }^{157}$ Though the plaintiffs argued that the union shop agreement "forces men into ideological and political associations which violate their right to freedom of conscience, freedom of association, and freedom of thought protected by the Bill of Rights," 158 the Court was not impressed. Implicating free-rider concerns, the Court stated that the disputed statutory provision simply required workers to pay financial support to the union "by all who receive the benefits of its work." 159 The Court found this limited statutory enactment was within the power of Congress under the Commerce Clause and did not violate either the First or the Fifth Amendments of the Constitution. ${ }^{160}$ The Court's analysis confirmed that First Amendment freedoms of thought, conscience and association do not invalidate the facial validity of union shop agreements. ${ }^{161}$ Freedom of expression, however, remained a possible basis for future relief ${ }^{162}$ "[i]f other conditions are in fact imposed, or if the exaction of dues, initiation fees, or assessments is used as a cover for forcing ideological conformity or other action in contravention of the First Amendment." 163

Moving beyond facial validity of union shop agreements, the Court next confronted the allegation that a labor union is not entitled to compel a worker to pay dues when such monies were, in substantial part, used to finance the campaigns of candidates for federal and state offices whom the dues objector opposed, and to promote the propagation of political and economic doctrines, concepts and ideologies with which he disagreed. ${ }^{164}$ In International Association of Machinists v. Street, the issue concerned the use of funds for purposes other than collective bargaining. First, we should note that the Court attempted by statutory construction to avoid dealing with the constitutionality of a union devotion of compulsory dues to political causes to which the employee payer objected. ${ }^{165}$ Instead, it

155. Beck v. Commc'n Workers of Am., 468 F. Supp. 93, 96 (D. Md. 1979).

156. Ry. Employes' Dep't v. Hanson, 351 U.S. 225 (1956).

157. GORMAN \& FINKIN, supra note 5, at 916.

158. Hanson, 351 U.S. at 236.

159. Id. at 238

160. Id.

161. Id.; see also GORMAN \& FINKIN, supra note 5, at 916-17 (discussing the relationship between the First Amendment and union shop agreements).

162. GORMAN \& FINKIN, supra note 5, at 916-17.

163. Hanson, 351 U.S. at 238.

164. Int'l Ass'n of Machinists v. Street, 367 U.S. 740, 744 (1961).

165. Id. at 748-49 ("Federal statutes are to be so construed as to avoid serious doubt of their constitutionality."); but see id. at 785 (Black, J., dissenting) (arguing that the Court should not rewrite the statute in order to avoid decisions on constitutional questions). 
justified the imposition of dues in order to deal with the free-rider problem. ${ }^{166}$ The Court, nonetheless, found that expending dues funds for political purposes was problematic. However problematic, the Supreme Court did not seem interested in remedies that would securely vindicate the First Amendment interests of dues objectors. The Court rejected the most direct remedy offered by the state court-an injunction against the union shop provision ${ }^{167}$-and as a substitute, the Court would permit union expenditures on political causes premised on the freedom of expression rights of the union majority. ${ }^{168}$ This approach does little to deal with an alternative conception of free speech that disallows all coerced speech in order to prevent all union attempts to enforce ideological conformity.

Two years after its decision in Street, "the Supreme Court clarified its position on the appropriate remedies in Brotherhood of Railway Clerks $v$. Allen." "The "Court invited the defendant unions to consider the adoption of some internal union plan providing for the designation of political expenditures, the manifestation of objections by members unwilling to contribute to such expenditures and an appropriate reduction in the moneys exacted from such objecting members." 170 The Court's approach invites those with the greatest access to information, the most influence on accounting procedures, and who are most likely to engage in a First Amendment violation to control the process that is designed to preclude ideological conformity.

Although earlier Supreme Court opinions had avoided dealing directly with the constitutionality of a union's use of coerced dues for political causes, ${ }^{171}$ the Court had to confront this issue directly in Abood. ${ }^{172}$ Abood "involved a collective bargaining agreement covered not by the National Labor Relations Act or the Railway Labor Act but rather by the state law of Michigan."173 "Under Michigan law, public sector employers and unions are authorized to agree to agency shop provisions"174 and the Michigan court construed the state statute to authorize the "use of such agency fees for purposes other than collective bargaining." 175 Dues objectors first

166. Id. at 761-63.

167. Id. at 771 .

168. See id. at 773 (discussing how the majority of the union has an interest in stating its views).

169. GORMAN \& FINKIN, supra note 5, at 918.

170. Id.; see also Bhd. of Ry. Clerks v. Allen, 373 U.S. 113, 122 (1963) (encouraging petitioner unions to consider the adoption of some voluntary plan by which dissenters would be afforded an internal union remedy).

171. GORMAN \& FINKIN, supra note 5, at 918.

172. Abood v. Detroit Bd. of Educ., 431 U.S. 209 (1977).

173. GORMAN \& FINKIN, supra note 5, at 918.

174. Abood, 431 U.S. at 211.

175. Id. at 232 . 
emphasized that government employment was involved, which directly implicated "constitutional guarantees in contrast to the private employment that was the subject of the Hanson and Street decisions." 176 Second, the plaintiffs/appellants argued "that in the public sector collective bargaining is inherently 'political' and that to require them to give financial support to [such bargaining] is to require 'ideological conformity' that the court expressly found lacking in Hanson." $" 177$ The Court found neither argument persuasive. ${ }^{178}$ Still, the Supreme Court determined that the exaction of funds to pay for the challenged expenditures, "over the protest of involuntary dues payers, interfered with their First and Fourteenth Amendment rights and was unconstitutional.,"179

This case has legs because "the principles announced there have been invoked in subsequent private-sector cases." ${ }^{180}$ Ensuing cases verify that political activities subject non-members to the risk of ideological conformity in violation of their free speech rights. On the other hand, since unions have incentives to engage in less than transparent accounting practices, ${ }^{181}$ prudent observers should be wary of surrendering to Gorman \& Finkin's contention that "it is relatively easy to identify when a union is expending dues moneys on 'ideological causes' and political candidates.", 182

In Ellis ${ }^{183}$ the Court provided a standard for deciding RLA cases. In Ellis, the complaining agency-fee payers acknowledged the legality of the agency-shop provision in the collective-bargaining contract between Western Airlines and the labor union. ${ }^{184}$ Still, they argued that dues objectors could not be compelled to contribute "more than their pro rata share of the expenses of negotiating agreements and settling grievances with Western Airlines." 185 The union conceded that the statute authorizing the union shop did not permit the use of petitioners' contributions for union political or ideological activities. Instead, they adopted a rebate program covering such expenditures. ${ }^{186}$ The parties disagreed "about the adequacy

176. Id. at 226 .

177. Id.

178. Id.

179. Gorman \& FINKIN, supra note 5, at 919; see also Abood, 431 U.S. at 236-37 (arguing that constitutional principles embedded in the First and Fourteenth Amendment prohibit unions from requiring any of the union dissidents to contribute to the support of an ideological cause that he may oppose as a condition of holding a job as a public school teacher).

180. GORMAN \& FinkIN, supra note 5, at 919.

181. See infra Part III.C (discussing how precedent can be used to reclaim First Amendment values).

182. GORMAN \& FINKIN, supra note 5, at 919.

183. Ellis v. Bhd. of Ry., Airline \& S.S. Clerks, 466 U.S. 435 (1984).

184. Id. at 439 .

185. Id.

186. Id. at $439-40$. 
of the rebate scheme, and about the legality of burdening objecting employees with six specific union expenses." ${ }^{187}$ The Supreme Court provided the following standard for RLA cases:

[O]bjecting employees may be compelled to pay their fair share of not only the direct costs of negotiating and administering a collective-bargaining contract and of settling grievances and disputes, but also the expenses of activities or undertakings normally or reasonably employed to implement or effectuate the duties of the union as exclusive representative of the employees in the bargaining unit. ${ }^{188}$

Applying this rule, the Court permitted union convention expenses, social activities, general publication expenditures, and litigation expenses that are directly related to the bargaining unit to be chargeable to union dues objectors. ${ }^{189}$ Concluding that Congress did not intend the union shop to aid the union in recruiting new members outside the bargaining unit, the Court found such expenses impermissible. ${ }^{190}$ Although this case was decided under the RLA, the Court's decision four years later in Communications Workers of America $v$. Beck signaled that the same governing principles apply under the NLRA. ${ }^{191}$

In Beck, the Supreme Court had to decide whether an exclusive bargaining agreement within the meaning of section 8(a)(3) of the NLRA ${ }^{192}$ "permits a union, over the objections of dues-paying nonmember employees, to expend funds so collected on activities unrelated to collective bargaining, contract administration, or grievance adjustment, and, if so, whether such expenditures violate the union's duty of fair representation or the objecting employees' First Amendment rights." 193 Decisions under the NLRA are made more complicated by virtue of the existence of an administrative agency, the NLRB. The Court of Appeals held that "because courts have jurisdiction over challenges to unionsecurity clauses negotiated under $\S 2$, Eleventh of the Railway Labor Act (RLA) ... which is in all material respects identical to $\S 8(\mathrm{a})(3)$, there must be a parity of federal jurisdiction over $\S 8(\mathrm{a})(3)$ claims." 194 Questions arise because unlike the NLRA, the RLA "establishes no agency charged with administering its provisions, and instead leaves it to the courts to determine the validity of activities challenged under the Act." 195 The Supreme Court

187. Id. at 435 .

188. Id. at 448 .

189. GORMAN \& FINKIN, supra note 5, at 923.

190. Ellis, 466 U.S. at 451.

191. GORMAN \& FinkIN, supra note 5, at 921-22.

192. 29 U.S.C. 158 (a)(3) (2000).

193. Commc'n Workers of Am. v. Beck, 487 U.S. 735, 738 (1988).

194. Id. at $742-43$.

195. Id. at 743 . 
answered this question by stating that the "primary jurisdiction of the NLRB . . cannot be diminished by analogies to the RLA, for in this regard the two labor statutes do not parallel one another."196 Still, the Court insisted "that $\S 8(a)(3)$ like its statutory equivalent, $\S 2$, Eleventh of the RLA, authorizes the exaction of only those fees and dues necessary to 'performing the duties of an exclusive representative of the employees in dealing with the employer on labor-management issues." "197 The Court concluded that while the NLRB has primary jurisdiction to decide unfair labor practice claims, the federal courts have collateral jurisdiction to decide unfair labor practice claims arising out of an asserted violation of the duty of fair representation. ${ }^{198}$ The district court found that only twenty one percent of the union's funds were expended on collective-bargaining activities. ${ }^{199}$ The district court also found that "the union's collection and disbursement of agency fees for purposes other than bargaining unit representation violated the associational and free speech rights of objecting nonmembers. ${ }^{200}$ On the other hand, convinced by Congress' free-riding rhetoric, the Supreme Court justified the application of $\S 8(\mathrm{a})(3)$ to all workers, ${ }^{201}$ but declined to decide Beck on First Amendment grounds.

In a subsequent case that arose in the public-sector, the Supreme Court in Lehnert v. Ferris Faculty Association engaged in a detailed inspection of disputed union expenditures by the Ferris Faculty Association (FFA), an affiliate of the Michigan Education Association (MEA) and the National Education Association (NEA) ${ }^{202}$ The FFA served as the exclusive bargaining representative of the faculty of Ferris State College, a public institution established under the Michigan Constitution and funded by the State. ${ }^{203}$ The Supreme Count articulated the following rule:

Hanson and Street and their progeny teach that chargeable activities must (1) be "germane" to collective-bargaining activity;

(2) be justified by the government's vital policy interest in labor peace and avoiding "free riders"; and (3) not significantly add to the burdening of free speech that is inherent in the allowance of an agency or union shop. ${ }^{204}$

The Court refused to require unions to "demonstrate a direct and tangible impact upon the dissenting employee's unit" before the challenged

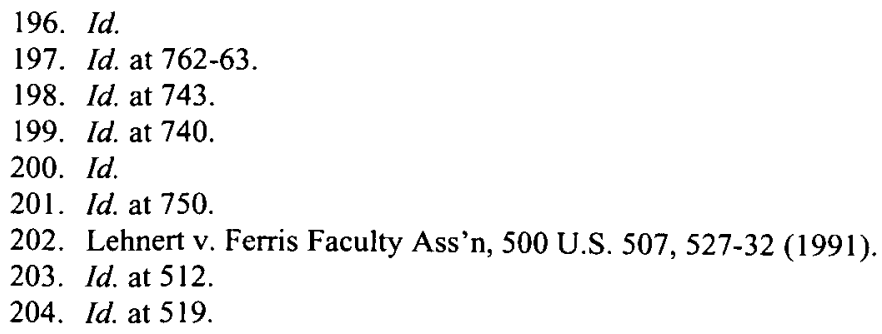


union activity could become chargeable. ${ }^{205}$ This refusal has consequences because it may encourage subsequent courts to conclude that a union does not act unlawfully by charging expenses that are ${ }^{206}$ "for services that may ultimately inure to the benefit of the members of the local union . . .."207 This may be a mistake "because virtually any activity may ultimately inure to the benefit of members."208 Indeed, the Court accepted the allegation that a local union's affiliation relationship with the national unit may provide "considerable economic, political and information resources when the local is in need of them."209 The Court's decision appears to allow activities that are questionable on their face to be charged to dues objectors. But, invoking Ellis, the Court held that the challenged expenses must be related to the union's "statutory functions" and its "overall bargaining goals." 210

Specifically, the Supreme Court disallowed the costs of a Preserve Public Education (PPE) program designed to secure funds for public education in Michigan because none of these activities were shown to be oriented toward the ratification or implementation of petitioners' collective-bargaining agreement and none could be chargeable to objectors. ${ }^{211}$ Litigation expenses that fail to concern the dissenting employees' bargaining unit are also nonchargeable. ${ }^{212}$ The Supreme Court determined that certain public relations expenditures designed to enhance the reputation of the teaching profession were impermissible because such activities involved speech of a political nature in a public forum. ${ }^{213}$ In addition, there is little connection between such expenditures and the union's collective-bargaining mission. ${ }^{214}$

On the other hand, the Supreme Court, consistent with its judgment that a union can charge objectors for activities that the union did not undertake directly on behalf of persons within the bargaining unit, allowed certain NEA program expenditures destined for states other than Michigan. ${ }^{215}$ The Court reasoned that such costs are part of general collective-bargaining expenditures of the state or national parent union and are therefore germane. ${ }^{216}$ Similarly, expenses related to teaching and

205. Id. at 522 .

206. Hutchison, A Clearing in the Forest, supra note 3, at 1385.

207. Lehnert, 500 U.S. at 524 (emphasis added).

208. Hutchison, A Clearing in the Forest, supra note 3, at 1385.

209. Lehnert, 500 U.S. at 523.

210. Id.

211. Id. at 527.

212. Id. at 528 .

213. Id.

214. Id.

215. Id. at 527 .

216. Id. 
education generally were permissible because such activities provided benefits for all, even though they were not directly related to bargaining unit concerns. ${ }^{217}$ On comparable grounds, certain convention expenditures incurred by both the state and national unit were found to be chargeable. ${ }^{218}$ Oddly, the Court allowed the union to charge objectors for expenses related to the preparation of a strike, which all parties conceded would have been illegal under Michigan Law. ${ }^{219}$ The Court determined that if the union had "actually engaged in an illegal strike, the union clearly could not have charged the expenses incident to that strike to petitioners." 220 But surrendering to speculation, the Court accepted that preparation for an illegal strike may strengthen the hands of the union and finding that "these expenses are substantively indistinguishable from those appurtenant to collective-bargaining negotiations" it allowed these expenditures to be chargeable to dues objectors. ${ }^{221}$ Because of the possibilities associated with language such as "strengthen" or "ultimately inure to the benefit of workers" combined with the failure to require that chargeable activities must provide a "direct and tangible benefit," Supreme Court jurisprudence appears to be highly contingent. The relevant question becomes, how far can the rules of decision drift from the idea that the First Amendment has substantive, as opposed to, linguistic content? One possible answer may be found in a recent appellate court decision rendered by the Ninth Circuit.

Consider the United Food case. In 2002, the Ninth Circuit Court of Appeals, finding that organizing is central to the purpose of the NLRA, ${ }^{222}$ issued a decision that allowed union organizing expenditures to be extracted from union dissenters. ${ }^{223}$ History may be helpful in understanding the evolution of this case. More than two decades ago, the U.S. Supreme Court categorically reversed a Ninth Circuit decision in Ellis regarding what constitutes a germane expenditure within the meaning of the RLA. ${ }^{224}$ In Ellis, the Ninth Circuit, had held that labor organizations were "entitled to charge [dues objectors] for their pro rata share of the union's organizing . . . expenses."225 The Supreme Court's reversal specified that "[o]rganizing money is spent on people who are not union

217. Id. at 529 .

218. Id. at 529-30.

219. Id. at 530-32.

220. Id. at 531 .

221. Id. at 532 .

222. United Food \& Commercial Workers Union, Local 1036 v. NLRB, 307 F.3d 760, 768 (9th Cir. 2002) (en banc).

223. Id. at 768-69 (adopting the NLRB's findings and determining that the Board's analysis is "in accord with the economic realities of collective bargaining, as well as with the language and purposes of the NLRA.").

224. Ellis v. Bhd. of Ry., Airline \& S.S. Clerks, 466 U.S. 435, 457 (1984).

225. Id. 
members, and only in the most distant way works to the benefit of those who already pay dues."226 Such expenditures are a "far cry from the freerider problem with which Congress was concerned."227 "The Court of Appeals found that organizing expenses could be charged to objecting employees because organizing efforts are aimed toward a stronger union, which in turn would be more successful at the bargaining table."228 The Supreme Court determined this "attenuated connection with collective bargaining [was] . . . outside Congress' authorization." 229 Despite this reversal, sixteen years later, the Ninth Circuit, once again, held that such activities were chargeable to dissenters. It offers the following reason. Although "organizing, which is conducted for the general purpose of strengthening the union, is not germane to collective bargaining under the RLA, the extra-bargaining unit organizing of competitor employers" ${ }^{\prime 230}$ can be germane under the NLRA so long as the administrative agency says so. ${ }^{231}$ Based largely on deference to the NLRB, the Ninth Circuit distinguished activities that are nonchargeable under the RLA from the same activities arising under the NLRA. From the Ninth Circuit's perspective, an objective of strengthening unions, vetted by an administrative agency, may ultimately inure to the economic benefit of all workers.

Conversely, a number of earlier cases found organizing expenses to be nonchargeable under the NLRA, the RLA, and public sector bargaining statutes. ${ }^{232}$ The Supreme Court offers instruction on this issue. In Beck, the Court stated that since section $8(a)(3)$ of the NLRA and section 2, eleventh of the RLA "are in all material respects identical,", ${ }^{, 233}$ RLA cases are "more than merely instructive," they are controlling for purposes of understanding the free-rider approach taken by Congress. ${ }^{234}$. If the Supreme Court is correct, it can be argued that union organizing expenditures are nonrepresentational and hence nonchargeable as a matter of law. That is, unless a court informed by exceptional insight can discover a tenable basis

226. Id. at 453 .

227. Id.

228. Id. at 451 .

229. Id.

230. United Food \& Commercial Workers Union, Local 1036 v. NLRB, 307 F.3d 760, 771 (9th Cir. 2002) (en banc).

231. Id at 774-75.

232. See Beck v. Commc'n Workers of Am., 776 F.2d 1187, 1211-12 (4th Cir. 1985) (declaring organizing to be nonchargeable); Lehnert v. Ferris Faculty Ass'n, 643 F. Supp. 1306, 1324 (W.D. Mich. 1986) (relying on Ellis and holding organizing nonchargeable in the public sector); United Food \& Commercial Workers, Local 1099, 327 N.L.R.B. 1237, 1244 (1999) (relying on Ellis to hold that organizing was nonchargeable under the NLRA); see also Hutchison, $A$ Clearing in the Forest, supra note 3, at 1367-69.

233. Commc'n Workers of Am. v. Beck, 487 U.S. 735, 745-47 (1988).

234. Id. at $746-47$. 
to escape the preclusive effect of both Ellis and Beck. The Ninth Circuit is just such a court. Although the U.S. Supreme Court denied a writ of certiorari, ${ }^{235}$ and though there is reason to disagree with the United Food court's analysis, ${ }^{236}$ the importance of the case lies elsewhere. The Ninth Circuit stakes its analytical powers on the contention that the ongoing decline in union density rates provides a justifiable basis to convert nonrepresentational activities into "germane," and therefore chargeable ones. This claim along with similarly capacious ones has the clout to swallow First Amendment values.

\section{Does Precedent Reclaim First Amendment Values?}

The Supreme Court, without necessarily drawing precise lines confirms that private-sector union political and ideological activities are not constitutionally chargeable to dissenting employees. ${ }^{237}$ Similarly, in Abood, the Court made a determination that a union utilizing an individual agency-shop agreement to force dissenting employees to subsidize ideological activities impermissibly impinges on objectors' rights within a public-employment context. ${ }^{238}$ Government "may not require an individual to relinquish rights guaranteed him by the First Amendment as a condition of public employment." ${ }^{, 239}$ Perhaps anticipating a dilemma that postmodern conflict makes plain, the Court states that because unions "traditionally have aligned themselves with a wide range of social, political and ideological viewpoints, any number of which might bring vigorous disapproval from individual employees, [forcing] employees to contribute ... to the promotion of such positions implicate[s] core First Amendment concerns."240 "Freedom of thought [as a core value] protected by the First Amendment against state action includes both the right to speak freely and the right to refrain from speaking at all.,"241

Although union dissenters might have reason to applaud such reasoning, difficulties remain. At least four questions suggest themselves including: (a) what counts as an ideological, political or otherwise nongermane expenditure; (b) do accounting issues cloud the proper answer to the first question; (c) is state action required to implicate pure freedom of speech and association analysis or are such considerations simply lurking

235. Mulder v. NLRB, 537 U.S. 1024 (2002).

236. Hutchison, A Clearing in the Forest, supra note 3, at 1368-94 (showing why the Ninth Circuit's analysis is unconvincing).

237. Lehnert v. Ferris Faculty Ass'n, 500 U.S. 507, 515 (1991) (citing Bhd. of Ry.

Clerks v. Allen, 373 U.S. 113 (1963)).

238. Id. at 516 (citing Abood v. Detroit Bd. of Educ., 431 U.S. 209 (1977)).

239. Abood v. Detroit Bd. of Educ., 431 U.S. 209, 234 (1977).

240. Lehnert, 500 U.S. at 516.

241. Id. at 516-17 (citing Wooley v. Maynard, 430 U.S. 705, 714 (1977)). 
in the background, particularly in private-sector cases; and (d) does freeriding analysis justify specific decisions taken by either the courts or the administrative agency.

First, labor unions aware of judicial precedent have an incentive to shield ideological and other nonrepresentational expenditures from scrutiny. A truthful response to the question of which expenditures are expended impermissibly may deprive unions of such funds. Unions have reason to blur the lines between germane and nongermane expenditures by suggesting that all expenditures are required to fulfill their collectivebargaining role. In addition, unions have not taken kindly to efforts by dues objectors to invoke their First Amendment rights. Dues objectors are likely to find the path of dissent "marked by threats of life and family, intimidation, insults and coercion." ${ }^{242}$ These difficulties are aggravated by the readiness of some courts to classify highly debatable union expenditures as germane even where the Supreme Court has reached the opposite opinion based on similar facts. ${ }^{243}$ On the other hand, Justice Scalia would hold "that any charge that does not relate to an activity expressly authorized by statute is constitutionally invalid, irrespective of its impact or lack thereof, on free expression."244 The majority opinion in Lehnert criticized Justice Scalia's approach as overly rigid because it failed to "acknowledge the practicalities of the complex interrelationship between public employers, employees, unions, and the public, ${ }^{, 245}$ but given such complexity, rigidity may bring welcome clarity.

Second, unions have predictably resisted requests to provide workers with information backed by an independent audit that conforms to ordinary norms of auditing. In the private-sector, resistance has been frequently supported by the NLRB. ${ }^{246}$ Indeed "[t]he Board [has] held that unions have no obligation to tell employees ... what percentage of dues are spent on nonrepresentational activities. ${ }^{.247}$ On the other hand, the Department of

242. Joe Knollenberg, The Changing of the Guard: Republicans Take on Labor and the Use of Mandatory Dues or Fees for Political Purposes, 35 HaRv. J. ON LEGIS. 347, 364 (1998).

243. See supra Part III.B. (discussing the legal precedent concerning first amendment rights in union dues adjudication).

244. Lehnert, 500 U.S. at 526 (discussing Justice Scalia's opinion concurring in the judgment in part and dissenting in part).

245. Id. at 526.

246. See Ferriso v. NLRB, 125 F.3d 865, 866 (D.C. Cir. 1997) (disagreeing with the NLRB and holding that if a union collects a compulsory agency fee, it is "required to provide [nonmembers] . . . with an independent audit"); Penrod v. NLRB, 203 F.3d 41, 45 46 (D.C. Cir. 2000) (overruling the NLRB's refusal to require a complete and thorough independent audit).

247. Penrod, 203 F.3d at 43. 
Labor has engaged in a welcome effort to increase union transparency. ${ }^{248}$ After litigating this issue before the U.S. Court of Appeals and losing, labor unions have predictably returned to politics in an effort to diminish transparency. Labor unions have succeeded in persuading the House of Representatives to reduce the amount of federal funds devoted to enforcing transparency norms which have highlighted labor unions' lavish spending in the past. ${ }^{249}$

Third, the Supreme Court refuses to consistently state that freedom from ideological conformity is firmly rooted in the Constitution and deserves robust protection. In determining whether sufficient state action exists to trigger First Amendment protection for private-sector cases arising under either the RLA or the NLRA, the Court appears to have two positions. For cases premised on the RLA, the Court conceded that Hanson determined "that because the RLA pre-empts all state laws banning union-security agreements, the negotiation and enforcement of such provisions in railroad industry contracts involves 'governmental action' and is therefore subject to constitutional limitations." ${ }^{250}$ For cases arising under the NLRA, the Court has stated that it is simply not required to decide that issue. ${ }^{251}$ While solicitous regarding First Amendment issues, the Court appears to prefer to escape grounding its decisions in the Constitution. Instead, it works around the Constitution and discovers an alternative basis for granting relief to dues objectors or rules against them. In the Beck case, for instance, the Court found that the duty of fair representation constituted a sufficient basis to grant dues objector's relief despite the District court's determination that "[the] disbursement of agency fees for purposes other than bargaining unit representation violated the associational and free speech right of objecting nonmembers. ${ }^{, 252}$ The Supreme Court avoided implicating the full import of its RLA decisions by claiming that the states have power to outlaw union-security agreements and hence "the federal pre-emption essential to Hanson's finding of

248. See Carl Horowitz, Union Accountability: Ruling Strengthens Financial Reporting, but Concerns Remain on Pension Funds, DeTROIT FreE PrEss, June 6, 2005, at 9A ("In a 30 decision, the U.S. Court of Appeals, District of Columbia Circuit, upheld a new set of regulations issued by the Department of Labor that required unions to spell out in greater detail how they spend their money.").

249. Diana Furchtgott-Roth, Extravagant Spending, N.Y. SUN, July 18, 2007, available at http://www.nysun.com/article/58667 (writing that while the members of the Appropriations Committee of the U.S. House of Representatives have voted to increase funding of all other oversight offices in the Labor Department, the Committee has voted to cut funds for the Office of Labor Management Standards which monitors union financial disclosure and that many of the leaders of this effort received more than $\$ 100,000$ in political contributions from labor unions).

250. Commc'n Workers of Am. v. Beck, 487 U.S. 735, 761 (1988).

251. Id.

252. See id. at 740 (discussing the lower court holding). 
governmental action is missing in the NLRA context." ${ }^{p 253}$ Although the Court's analysis of cases arising under the NLRA is not fully persuasive in all respects, it is clear that sufficient governmental coercion exists in a public employment context to implicate First Amendment rights. ${ }^{254}$

Fourth, adjudication is commonly driven with free riding presumptions that are fortified by an insufficiently robust understanding of human self-interest. Since I have discussed judicial free riding deficiencies extensively elsewhere, ${ }^{255} \mathrm{I}$ offer only two points here. First, labor unions are made up of diverse workers with disparate interests and preferences, and therefore, consistent with the parameters of postmodern discourse and Madisonian assumptions, it is impossible to believe that workers necessarily share a common interest. In the absence of a common interest, the likelihood of free riding by dissenting workers plummets.

While strategic behavior within a labor union setting may create plausible opportunities that produce positive externalities wherein individuals obtain goods without bidding for them, free riding produced by interest convergence may not necessarily exist-since interest convergence itself may not exist. In neoclassical economic and welfare terms, the disutility associated with mandatory union membership may outweigh the putative utility (if any exists at all) of such membership. ${ }^{256}$

The pursuit of special-interest goods provides concentrated (largely private) benefits to the few. ${ }^{257}$ When courts and administrative agencies frame this pursuit exclusively as a limited search for economic benefits obtainable by represented workers including union dissenters, this maneuver supplies cover for the true beneficiaries' self-interest. ${ }^{258}$ "Operationally, judicial cover is provided by an inadequate search for all self-interested benefits attached to the challenged union activity."259 Since

253. Id at 761 .

254. See, e.g., Abood v. Detroit Bd. of Educ., 431 U.S. 209, 234 (1977) (finding that appellants could refuse to associate with a union's spending program that required them to contribute to political candidates and to express political views unrelated to the union's duties as the exclusive bargaining representative).

255. See, e.g., Hutchison, Reclaiming the Union Movement Through Union Dues, supra note 3, at 483-92 (describing types of free and forced riding); see also Hutchison, $A$ Clearing in the Forest, supra note 3, at 1388-90 (disputing the courts and Judge Richard Posner's free riding approach).

256. Hutchison, A Clearing in the Forest, supra note 3, at 1324-25.

257. See Jane S. Shaw, Public Choice Theory, in The Fortune EnCyClopedia of ECONOMICS 150-51 (David R. Henderson ed., 1993) (pointing out that because voters are often rationally ignorant, legislators may be captured by lobbying groups who provide campaign funds in exchange for support for legislation that may provide largely private benefits for the group).

258. Hutchison, $A$ Clearing in the Forest, supra note 3, at 1391.

259. Id. 
self-interest implicates both economic and ideological goals, engaging in an inadequate search enables courts to overlook self-interested benefits (private externalities) that disproportionately accrue to union hierarchs and union outsiders that may have captured the union, its policymaking and its revenues. ${ }^{260}$ This move permits courts to overestimate the self-interested benefits obtainable by represented workers in connection with any contestable union expenditure. The adverse effects of this move for dues objectors is worsened because the Supreme Court fails to require that unions demonstrate a direct and tangible impact upon the dues objector's unit before the contested activity becomes chargeable. Instead the courts allow unions to charge for services that may ultimately inure to the benefit of the local union. ${ }^{261}$ Unions, thus, have wide scope for their activities.

\section{THE DAVENPORT CASE}

The Davenport case represents the consolidation of two cases that have endured a long and torturous litigation process. The issue to be decided was whether a Washington State Fair Campaign Practices Initiative, as applied to public sector unions, was permissible.

\section{A. The Washington State Courts}

Washington State voters adopted an initiative amending the state's regulation of political contributions and campaign expenditures during the fall of $1992 .{ }^{262}$ The amendment, also known as $\S 760$, constrains labor unions in the following manner: "A labor organization may not use agency shop fees paid by an individual who is not a member of the organization to make contributions or expenditures to influence an election or to operate a political committee, unless affirmatively authorized by the individual.,"263

260. Id.

261. Lehnert v. Ferris Faculty Ass'n, 500 U.S. 507, 524 (1991) (holding that a local bargaining representative may charge objecting employees for their share of the costs associated with other chargeable activities of its state and national affiliates, even if those activities were not performed for the direct benefit of the objecting employees' direct bargaining unit).

262. Initiative Measures-Political Contributions and Campaign Expenditures, 1993 Wash. Legis. Serv. (West) (1993).

263. Initiative Measures-Political Contributions and Campaign Expenditures, 1993 Wash. Legis. Serv. (West), Part III, § 16 (1993); see also, Davenport v. Wash. Educ. Ass'n, 127 S. Ct. 2372, 2377-78 (2007) (citing $\$ 760$ as it stood when the trial court decision was rendered). Subsequently, the initiative was amended in 2007 . This amended version of the initiative does not concern us here except as an illustration of the fragility of state initiatives. Washington has since adopted an amended version of the initiative to codify a narrower interpretation of the "use" of agency-shop fees than the interpretation adopted by the trial court. See, e.g., Davenport, 127 S. Ct. at 2377 n.l (citing that this amendment does not 
The respondent union, the WEA, litigated its extraction of nonmembers' agency fees in two lawsuits. ${ }^{264}$ Both suits claimed that the respondent's use of agency fees was in violation of $\S 760 .^{265}$ The Washington State Supreme Court held that $\S 760$ was unconstitutional within the meaning of United States Supreme Court precedents. ${ }^{266}$

The WEA is the exclusive bargaining agent for approximately 70,000 state educational employees and membership in the union is voluntary. ${ }^{267}$ But members and nonmembers must contribute to the WEA for the costs related to collective bargaining. Per statute, members pay dues to the union; nonmembers pay agency shop fees, which are equivalent to member dues. ${ }^{268}$ Accepting the allegation that it is well settled that a union, which is obliged to act on behalf of all employees in the bargaining unit, may charge nonunion employees to bear their "fair share" of the costs of representation $^{269}$ and basking in the assertion that Washington has a long and proud history of being a pioneer in the protection of employee rights, ${ }^{270}$ the Washington State Supreme Court approved agency shop provisions that require the deduction from nonmembers' salary of fees equivalent to union dues. ${ }^{271}$ The state court acknowledged that a "portion of members' dues goes to support political and ideological causes, which are unrelated to the union's collective bargaining activities" 272 and determined that these expenses are typically called non-chargeable expenses. ${ }^{273}$ However nonchargeable such expense may be, in order for nonmembers to escape from objectionable political and ideological expenses, they must submit to a rebate procedure requiring compliance with opt-out rules set forth by the U.S. Supreme Court in Hudson. ${ }^{274}$

affect the court's analysis of whether $\S 760$ 's affirmative-authorization violates the constitutional rights of respondent).

264. Davenport, 127 S. Ct. at 2378 (citing two lawsuits claiming that respondent's use of agency fees was in violation of $\S 760$ ).

265. Id.

266. Id.

267. Id. at 2377-78.

268. State ex rel. Wash. State Pub. Disclosure Comm'n v. Wash. Educ. Ass'n, 130 P.3d 352, 354 (Wash. 2006).

269. Id. at $354 \mathrm{n} .1$ (citing a Supreme Court case in which the Court found it was well settled that a union could require nonunion employees to bear their fair share of the costs of representation).

270. Id.

271. Id. at 354 n.2.

272. Id. at 354 .

273. Id.

274. Id. at 365 . Hudson's minimum constitutionally permissible standard apparently includes as a predicate to a union's collection of agency fees: (A) an adequate explanation of the basis for the fee, (B) a reasonably prompt opportunity to challenge the amount of the fee before an impartial decision-maker and (C) an escrow for the amount reasonably in 
Dissenting agency-fee payors were sent Hudson packets, but failed to comply with the Hudson's procedures. ${ }^{275}$ Though the union's approach did not satisfy $\S 760$ 's affirmative-authorization requirement as a matter of state law, the state court, nevertheless, invalidated the initiative because it imposed rules on unions that violated the First Amendment of the Federal Constitution. ${ }^{276}$ The state supreme court decision found that United States Supreme Court's agency-fee jurisprudence established a balance between the First Amendment rights of unions and of nonmembers, and that $\S 760$ required heightened First Amendment scrutiny because it deviated from that balance by imposing on the union the burden of confirming that a nonmember does not object to the expenditure of his agency fees for electoral purposes. ${ }^{277}$ Further, the court "held that $\S 760$ interfered with respondent's expressive associational rights under Boy Scouts of America v. Dale, 530 U.S. 640 (2000).,278

\section{B. The Supreme Court Ruling}

The U.S. Supreme Court's review of the consolidated caseDavenport v. Washington Education Association-turned primarily on whether the state's restriction on the use of labor unions' agency-shop fees violated rather than reclaimed the First Amendment. ${ }^{279}$ The Court concluded that the "National Labor Relations Act leaves States free to regulate their labor relationships with their public employees." ${ }^{280}$ States have the authority to authorize a union and a government employer to enter into what is commonly known as an agency-shop agreement. This arrangement entitles the union to levy a fee on employees who are not union members but who are represented by the union in collective bargaining. ${ }^{281}$ Though the Court agreed that the primary purpose of this arrangement is to prevent nonmembers from free riding on the union's collective bargaining activities without sharing the costs incurred, the Court acknowledged that public-sector agency-shop arrangements implicate First Amendment concerns. ${ }^{282}$ The Court resolved that (A) compulsory dues payments by nonmembers can only be sustained by the Court's free-riding jurisprudence when the union engages in collective-bargaining efforts as

dispute while such challenges are pending. Chicago Teachers Union v. Hudson, 475 U.S. 292,310 (1986).

275. Davenport v. Wash. Educ. Ass'n, 127 S. Ct. 2372, 2378 (2007).

276. Id.

277. Id.

278. Id.

279. Id. at 2376 .

280. Id. (citing 49 Stat. 450 , as amended, 29 U.S.C. $\S 152(2)$ ).

281. Id at 2376-77.

282. Id. at 2377. 
opposed to union political advocacy or other non-germane actions and (B) First Amendment values are implicated when agency-shop arrangements compel individuals to contribute money to unions as a condition of government employment. ${ }^{283}$

The basic argument advanced by the Washington Education Association (WEA) for invalidating the Washington State Initiative-the Supreme Court's First Amendment jurisprudence in the agency-fee arenaappeared to be less than credible. Hence, the entire Court had little trouble dismissing most of the union's various contentions. First, the Court found that "it is undeniably unusual for a government agency to give a private entity the power, in essence, to tax government employees." 284 The state of Washington had imposed only a modest limitation upon this extraordinary power by conditioning the union's use of nonmembers' agency fees for election-related purposes on each nonmember's prior consent. ${ }^{285}$ The union admitted that the state could have gone further by "restricting public-sector agency fees to the portion of union dues devoted to collective bargaining."286 Concluding that "it would be constitutional for Washington to eliminate agency fees entirely, ${ }^{287}$ the Supreme Court effectively issued an invitation to all of the states to do likewise and insisted "that the far less restrictive limitation the voters of Washington placed on respondent's authorization to exact money from government employees is of no greater constitutional concern." 288

Secondly, the Supreme Court held that its agency-fee cases neither balanced the constitutional rights of unions and nonmembers, nor dictated that a nonmember must shoulder the burden of objecting before a union could be barred from spending his fees for purposes impermissible under Abood. ${ }^{29}$ Attempting to sustain its analysis, the Washington State Supreme Court appealed to the following proposition: “"[D]issent is not to be presumed-it must affirmatively be made known to the union by the dissenting employee." ${ }^{290}$ This appeal is dubious because "unions have no constitutional entitlement to the fees of nonmember-employees" ${ }^{291}$ in the first place. No authority supports the claim that the First Amendment is implicated to protect unions "whenever governments place limitations on a union's entitlement to agency fees above and beyond what Abood and

283. Id.

284. Id. at $2378-2380$.

285. Id. at 2378 (emphasis added).

286. $I d$.

287. Id.

288. Id. at 2379 .

289. Id. at 2378-2379.

290. Id. at 2379 (citing Chicago Teachers Union v. Hudson, 475 U.S. 292, 306 n.16 (1986) (quoting Int'l Ass'n of Machinists v. Street, 367 U.S. 740, 774 (1961))).

291. Id. 
Hudson require."292 Equally plain, the Hudson procedures simply outline "a minimum set of procedures by which a [public sector] union in an agency-shop relationship could meet its requirement under Abood."293 Although $\S 760$ requires more than the constitutional (Hudson) minimum, this move cannot trigger First Amendment scrutiny because the constitutional floor for unions' collection and spending of agency fees is not a constitutional ceiling for state-imposed restrictions. ${ }^{294}$ The Supreme Court's rejection of the allegation that dissent should not be presumed appears to fortify the First Amendment rights of an increasingly diverse workforce by setting the stage for objectors to contest all activities engaged in by labor unions.

Thirdly, the Court found that the enactment of $\S 760$ was permissible under the Court's campaign-finance jurisprudence. ${ }^{295}$ Despite this, the respondent contended that the rigorous First Amendment scrutiny required by precedent mandated that " $\$ 760$ is unconstitutional because it [limits how the union can spend its money] and because it does not limit equivalent election-related expenditures by corporations." ${ }^{\text {296 }}$ The Court, however, disagreed:

For purposes of the First Amendment, it is entirely immaterial that $\S 760$ restricts a union's use of funds only after those funds are already within the union's lawful possession under Washington law. What matters is that public-sector agency fees are in the union's possession only because Washington ... [has] compelled their employees to pay those fees. ${ }^{297}$

The WEA wrongly relied upon cases that dealt with governmental restrictions on how a regulated entity might spend money that had come into its possession without government coercion of its employees. ${ }^{298}$ As applied to public-sector unions, $\S 760$ cannot be described as a restriction on how the union spends its money; instead, "it is a condition placed upon the union's extraordinary state entitlement to acquire and spend other people's money"299 and the voters are entitled to have a different opinion

292. Id.

293. Id

294. Id. (emphasis added).

295. Id. at 2383 (Breyer, J., dissenting).

296. Id. at 2380 .

297. Id.

298. Id.

299. Id. 
about non-coercively acquired corporate funds. ${ }^{300}$ The Court dismissed the union's expressive/associational rights contentions as well. ${ }^{301}$

The fourth question-whether the voters of Washington acted to impermissibly distort the marketplace of ideas when they placed a reasonable, viewpoint-neutral limitation on the State's general authorization allowing public-sector unions to acquire and spend the money of government employees-can be answered rather easily if one agrees with the Washington State Supreme Court. The court recognized that the voters acted to maintain the integrity of the election process. ${ }^{302}$ Since the voters acted to protect the election process, and since the speech, at issue, is entirely proscribable, "content-based regulation is permissible so long as 'there is no realistic possibility that official suppression of ideas is afoot." "303 The same answer is obtained "when, as here, an extraordinary and totally repealable authorization to coerce payment from government employees is at issue. "304 Justice Scalia did not find any suppression of ideas afoot because "the union remains as free as any other entity to participate in the electoral process with all available funds other than the state-coerced agency fees lacking affirmative permission." 305 Since the state has the constitutional power to deprive labor unions of the authority to coerce entirely, that authority persists when the state imposes a less comprehensive limitation on unions' power.

In answering the fifth question-whether $\S 760$ unconstitutionally draws distinctions based on the content of the union's speech-Justice Scalia reviewed the landscape. He acknowledged that content-based regulations of speech were presumptively invalid because content-based discrimination raised the specter that the government was attempting to drive certain ideas or viewpoints from the marketplace. ${ }^{306}$ Here, however, the Court declared that it is impossible to "believe that the voters of Washington impermissibly distorted the marketplace of ideas when they placed a reasonable, viewpoint-neutral limitation on the State's general authorization allowing public-sector unions to acquire and spend the money of government employees. ${ }^{, 307}$ In truth, one might argue that the opposite is true. By depriving the marketplace of all compulsorily-obtained funds the Supreme Court, consistent with its precedents in Abood and Hudson,

300. Id.

301. See id. at n.2. (stating that the Washington court's invocation of the union's expressive associational rights, as a basis for invalidating $\S 760$, was largely abandoned by the WEA before the U.S. Supreme Court).

302. Id. at 2381.

303. Id.

304. Id. at 2381-2382.

305. Id. at 2382 .

306. Id. at $2380-2381$.

307. Id. at 2381 . 
signals that "whatever the amount[at issue], the quality of [union dissenters'] interest in not being compelled to subsidize the propagation of political or ideological views that they oppose is clear." ${ }^{308}$ The Supreme Court's alarm vindicates Thomas Jefferson and James Madison's interest in precluding tyranny that is facilitated by the forced extraction of any amount "for the "propagation of opinions [any citizen] disbelieves.",309 Because the Washington voters sought to protect the integrity of the election process, which they believed was being impaired by the infusion of nonmembers' money, the restriction on the state-bestowed entitlement was permissibly limited to the state-created harm that the voters sought to remedy. ${ }^{310}$

The Supreme Court majority recognized that the rights of nonmembers might not necessarily warrant judicial interference with a union's statutory entitlement. ${ }^{311}$ Judicial reluctance, taking the form of a refusal to hinder a union's entitlement by stoutly sustaining dissenters' freedom of expression rights, may create a void as well as a basis for mischief. This lacuna in earlier cases has led to difficulty in exercising freedom of expression rights. ${ }^{312}$ Nonetheless, the entire Court concluded that judicial hesitation "does not imply that legislatures (or voters) themselves cannot limit the scope of that entitlement." 313 The WEA could not convincingly claim its First Amendment rights trumped the constitutional rights of nonmembers to prevent the union from spending their dues on nongermane activities when the state, through its legislature or its voters, so limited the union's entitlement to agency fees. The Supreme Court dismissed the union's First Amendment counter-claims and insisted that dissenting workers' First Amendment rights retain their vitality.

Lastly, the Court limited its holding to public-sector cases despite the fact that $\S$ "760 applies on its face to both public- and private-sector unions in Washington.",314 "Since private-sector unions collect agency fees through contractually required action taken by private employers rather

308. Chicago Teachers Union v. Hudson, 475 U.S. 292, 305 (1986). (emphasis added).

309. Id.

310. Davenport, 127 S. Ct. at 2381.

311. Id. at 2379-80.

312. See, e.g., Hutchison, A Clearing in the Forest, supra note 3, at 1327 ("The Beck Court's . . . approach failed to supply a clear enforcement mechanism or clear principles. Consequently, this has led to problems in exercising Beck rights."); see also United Food \& Commercial Workers Union, Local 1036 v. NLRB, 307 F.3d 760 (9th Cir. 2002) (en banc) (enforcing an NLRB order requiring dues objectors to pay for union organizing expenditures that are arguably non-germane despite the U.S. Supreme Court's holding in Ellis v. Bhd. of Ry., Airline \& S.S. Clerks, 466 U.S. 435 (1984) which disallowed such expenditures).

313. Davenport, $127 \mathrm{~S}$. Ct. at 2379-80.

314. Id. at 2382 . 
than by government agencies, Washington's regulation of such private arrangements presents a somewhat different constitutional question."315 Refusing to answer this question, Justice Scalia's opinion upheld $\S 760$ only as applied to public-sector unions. ${ }^{316}$ Though he insisted that privatesector restrictions present a different question than public-sector ones, that contention raises a more salient reply inquiry: Does an effort to find a difference between private-as opposed to public-sector labor union compulsion constitute an elusive search for an illusion?

While the Davenport Court insists that the rights of workers can be protected by state restrictions on labor union power, and while Washington State's limitation "actually advance[d] First Amendment values by safeguarding the interest of nonmembers in not having to pay for union political activities with which they disagree, ${ }^{, 317}$ Justice Scalia's failure to answer the last question posed by Davenport's facts suggests union dissenters should embrace referenda and legislation cautiously for at least two reasons. First, such referenda and legislation must be interpreted by the courts. However insistent the Supreme Court may be regarding union dissenters' free speech rights, reluctant adjudication persistently places First Amendment values in harm's way. Second, given the Court's constrained conception of government coercion, prior deficiencies in its free rider jurisprudence, its current failure to breathe life into the facts and implications of Beck and Lehnert cases, and the virtually unlimited basis for disagreement among citizens, it seems obvious that dissenting workers in the state of Washington and elsewhere should refrain from celebrating what may be a negligible victory.

\section{CAN DAVENPORT RECLAIM FIRST AMENDMENT VALUES?}

On a number of levels, the Davenport opinion reflects an enduring conflict regarding the nature of liberalism and liberal values, including the First Amendment. Christopher Shannon intimates that classical liberals viewed rationality as existing within the individual, whereas contemporary liberals, and by extension the union hierarchs within their ranks, appear to see rationality in large institutions. ${ }^{318}$ In contrast to contemporary liberalism of the compulsory variety, it might be argued in Lockean terms that a worker as a "true agent" is an individual who, "according to his own light and the sense of right and wrong, causes his own actions, without

315. Id.

316. Id.

317. Brief for the United States as Amicus Curiae Supporting Petitioners at 9, Davenport v. Wash. Educ. Ass'n, 127 S. Ct. 2372 (2006) (Nos. 05-1589 and 05-1657).

318. SHANNON, supra note 152, at 147. 
undue external influence." 319 Freedom on one account allows one to "go beyond individual and collective selfishness and reach out to that which reason perceives as objectively good and true." 320 "The agent is, of course, determined to act the way he does, for otherwise his action would be arbitrary. But the source of the determination of his will is ultimately internal to him and subject to rational scrutiny",321 and lies beyond involuntary conformity. It is not clear that Lockean views can be relied upon in a world where philosophical liberalism may be an impossibility and political liberalism may be nothing more than an "unprincipled modus vivendi . . devoid of deep conviction., ${ }^{323}$ Nonetheless, viewpoint diversity internalized in workers and grounded in deep conviction that gives space for individuals to enjoy the right to do what they ought ${ }^{324}$ appears to operate consistently with First Amendment values and weakens prevailing conceptions of labor union solidarity that require workers to act, if not think, uniformly.

Postmodernism may help society discover three possibilities. First, postmodernism may help reclaim the search for life-purpose as well as the formerly invisible (traditional) sources of diversity and places the notion of group interest and preference uniformity in the crosshairs by showing that the sources and the depth of conflict are increasing. The persistence of postmodernism, the likelihood of group capture, and the search for lifepurpose (within or outside of classical liberalism) coalesce to formulate conditions that impair the prospect of finding a present-day basis for worker interest and preference uniformity.

Second, postmodernism illuminates the difficulties that labor unions face today. Such difficulties may drive unions toward coercion. Labor unions, battered by the vagaries of modern and post-Enlightenment history including declining union density rates, burdened by the irreparable disintegration of solidarity and brooding heavily on the unlikely possibility of recapturing their former ascendancy have succumbed, as public choice theory predicts, to the incentive to pursue hegemony through politics funded by compulsory contributions.

319. Andrzeis Rapaczynski, Nature and Politics: Liberalism in the Philosophies OF HOBBES, LOCKE, AND ROUSSEAU 176 (1987) (discussing Locke).

320. Avery Cardinal Dulles, Truth as the Ground of Freedom: A Theme of John Paul II, in Recovering Self-Evident Truths: Catholic Perspectives on American Law 69, 72 (Michael A. Scaperlanda \& Teresa Stanton Collett eds., 2007).

321. RAPACZYNSKI, supra note 319 , at 176.

322. Larry Alexander, Illiberalism All the Way Down: Illiberal Groups and Two Conceptions of Liberalism, 12 J. CONTEMP. LEGAL IsSUES 625, 625 (2002).

323. Id.; see also Eric R. Claeys, John Locke's General Theory of Free Association (forthcoming) (on file with author).

324. Dulles, supra note 320, at 73 (quoting Lord Acton). 
Third, if postmodern discourse is adopted by courts, commentators and even union hierarchs, this may make it more difficult to reconstruct a principled ground for protecting liberty of conscience, association, and expression. Postmodern discourse may deprive us of the language necessary to reclaim rights and freedom within any contestable context. This possibility may return us to Alasdair MacIntyre's dilemma, wherein human history provides no sound basis for rights. MacIntyre points out that rights attaching to human beings simply qua human beings found no expression in any ancient or medieval language until the close of the middle ages. ${ }^{325}$ Equally clear, the adjudication of rights attaching to union dues dissenters qua dissenters may be submerged in imaginative adjudication that is grounded in the Supreme Court's deference to its own version of modern liberalism: cosmopolitan explication. This may leave dissenters without sufficient language to challenge adjudication, which worryingly, may leave authoritarianism and compulsion in place.

Given the level of political spending that typically plagues publicsector unions ${ }^{326}$ and the diversity of views available within the workforce, it may be difficult to take seriously the Supreme Court resolution of a dispute involving less than one-fourth of one percent of the WEA's total expenditures. ${ }^{327}$ This is particularly so, since the year after the law went in to effect, ${ }^{328}$ the WEA "actually increased the amount it spent to influence politics by 60 percent. ${ }^{, 329}$ Though grounds for skepticism may engulf the capacity of the Davenport case to empower dues objectors to reclaim First Amendment values, grounds for optimism can be found in the Court resolution of two issues: (A) that the state of Washington could constitutionally eliminate agency fees entirely in order to protect workers' rights to their own money and (B) that the citizens of Washington are not bound by the allegation that dissent within labor unions cannot be presumed.

First, although the Court rightly concluded that Washington's citizens could eliminate agency fees affecting public-sector workers and privatesector workers covered by the NLRA, it is not necessarily true that the citizens have the right to preclude similar agency/nonmember fee arrangements involving dues objectors arising under the RLA. In Hanson, the Supreme Court noted that the 1951 amendment to the RLA permitted the negotiation of union shop agreements, and expressly allowed those

325. EDMUNDSON, supra note 153, at 4-5 (discussing MacIntyre).

326. See supra Part I.B (discussing Leo Troy's information).

327. See Mix, supra note 20 (noting that one party who filed an amicus brief pointed out that the funds covered by the statute amounted to less than one-fourth of one percent of the WEA's total expenditures).

328. Id.

329. Id. 
agreements notwithstanding any law "of any State." ${ }^{, 30}$ It appears that the citizens of Washington do not have unlimited authority, through either paycheck protection or right-to-work legislation, to protect the rights of all workers to their own money.

Turning to the second issue, wherein the Court disputes the credulous contention that dissent is not to be presumed, labor unions, relying on this presumption, have attempted to shield their ability to forcibly extract funds from scrutiny premised on the thin claim that all workers receive the benefits of their advocacy. The Supreme Court's rejection of this claim constitutes an attractive vehicle for restoring honesty to the union dues debate. Appeal is enhanced because the Court affirmatively stated that "unions have no constitutional entitlement to the fees of nonmemberemployees." ${ }^{\text {"31 }}$ This declaration is consistent with the notion that conflict not agreement is the norm in our society. In a post-Enlightenment world that has recaptured the search for life-purpose as well as the formerly invisible sources of diversity, it seems impossible not to presume dissent. No longer captive to the myth of "universal" workers presumably bound together in a common struggle against management, courts have the opportunity to vitiate free-rider presuppositions and confront the fact that self-interest drives union leaders and their ideological allies just as much as it drives represented workers. This enables courts to see conflict, not agreement, as the background from which union dues disputes surface. Illuminated by the presence of dissent, the Court and the courts have a basis to revisit free riding presumptions and reconsider union claims that a contested policy will ultimately inure to the benefit of disapproving workers.

Despite these two grounds for optimism, it is possible to see the Davenport case as a continuation of highly flexible First Amendment adjudication that undermines First Amendment values. Three reasons present themselves. First, although $\S 760$ applies on its face to both publicand private-sector unions, the Davenport Court could not find a basis to validate the $\S 760$ with respect to private-sector workers. This is troubling because it is difficult to separate public- from private-sector labor unions. ${ }^{332}$ Prior Court decisions rested on the absence of state action, the difficulty of finding governmental coercion, ${ }^{333}$ the presence of a duty of fair

330. Ry. Employes' Dep't v. Hanson, 351 U.S. 225, 232 (1956).

331. Davenport v. Wash. Educ. Ass'n, 127 S. Ct. 2372, 2379 (2007).

332. See infra p. 712(discussing difficulties in drawing lines between public- and private-sector unions).

333. Commc'n Workers of Am. v. Beck, 487 U.S. 735, 761 (citing Hanson, 351 U.S. 225 for the proposition that it is possible to find government coercion where the RLA preempts all state law banning union security agreements). 
representation, ${ }^{334}$ or on the claim that the Court need not answer the question. ${ }^{335}$ If a state fails to outlaw private-sector union-shops and union security agreements sanctioned by the NLRA, it appears that just as much governmental coercion is present as the Court has found in cases arising under public-sector bargaining statutes. Private-sector employers and labor unions operating under the aegis of the NLRA or the RLA were ceded authority by the Federal government to coerce private sector dues payments from dissenting employees, enforceable through the right to terminate workers for nonpayment of dues. ${ }^{336}$ The Court's failure to affirmatively state that Washington State's paycheck protection referenda ought to apply to private-sector unions appears to avoid some, but not all of the force of Justice Scalia's Lehnert opinion with respect to public-sector disputes. As previously indicated, he would vindicate First Amendment freedoms by precluding unions from charging objectors for any expense that did not relate to an activity expressly authorized by statute, irrespective of its impact or lack thereof, on free expression. ${ }^{337}$ Embracing and extending the logical force of Justice Scalia's Lehnert proposal to constitutionally invalidate all such activities in both the private- and public-sector might be a positive step in reestablishing the rights of all workers to be free from ideological conformity in a nation in which it is difficult to draw lines between public- and private-sector unions.

Second, the Davenport opinion affirms the Supreme Court's problematic approach to free-riding. Free-riding constitutes the primary justification for agency-fee arrangements. ${ }^{338}$ It would be constructive for the Court to explain how the union activity at issue benefits nonmembers before valorizing agency-fee arrangement on free-riding grounds. It would also be constructive for the Courts to place a heavy burden of proof on unions and require them to show beyond a reasonable doubt ${ }^{339}$ that represented workers receive a direct and tangible economic benefit before

334. Beck, 487 U.S. at 738 (stating it must decide whether the duty of fair representation applies).

335. See, e.g., Beck, 487 U.S. at 761 (citing Steelworkers v. Sadlowski, 457 U.S. 102, 121 n.16 (1982)) (implying that neither state action nor government coercion can be found under the NLRA, but ultimately stating it need not decide that issue).

336. GORMAN AND FINKIN, supra note 5, at 907 (noting an employee's job under a union shop provision can be terminated for failure to satisfy his or her "financial core" obligations).

337. Lehnert v. Ferris Faculty Ass'n, 500 U.S. 507, 526 (1991).

338. Davenport v. Wash. Educ. Ass'n., 127 S. Ct. 2372, 2377 (2007).

339. This approach would go beyond the Supreme Court's statement in Allen that unions simply bear the burden of proving the proportion of union revenues devoted to political and ideological speech. See Bhd. of Ry. Clerks v. Allen, 373 U.S. 113, 122 (1963) ("Since the unions possess the facts and records from which the proportion of political to total union expenditures can reasonably be calculated, basic considerations of fairness compel that they, not the individual employees, bear the burden of proving such proportion."). 
the Court and the courts permit free-rider analysis to provide cover for challenged expenditures. This is not to say unions fail to provide any benefits to represented workers but to suggest that the Court has been unprepared to fully explore these issues. As previously established, the lower courts in Lehnert and Beck had engaged in a detailed analysis of union expenditures. They found that most union activities did not provide collective-bargaining benefits. Without self-interested benefits, free-rider presumptions collapse. This result is reinforced when courts, conversant with the implication of postmodernism, informed by workers' search for life-purpose and knowledgeable of the formerly invisible sources of diversity, accept the impossibility of preference and interest uniformity. Without uniformity, the Court and the courts' attitude toward free-riding surfaces as an anachronism.

Third, the Supreme Court continues to discount the rights of dues objectors by insisting on the validity of the Hudson rule. The Court stated, "Neither Hudson nor any of our other cases . . . has held that the First Amendment mandates that a public-sector union obtain affirmative consent before spending a nonmember's agency fees for purposes not chargeable under Abood." ${ }^{340}$ The Davenport Court's affirmation of the validity of this approach seems irreconcilable with a principled and energetic approach to freedom of speech. The Davenport Court's free-rider and First Amendment analysis taken together imply that compulsory dues payments for political, ideological and other non-germane purposes impermissibly impinge on the constitutional rights of dissenting workers. It follows, therefore, that consent ought to be required before the burden of ideological, political and other non-germane expenditures can be imposed on dissenters. Instead, the Court commands something less than consent. ${ }^{341}$

Furthermore, it can be argued that political and ideological expenses that have an ostensibly germane purpose ought to implicate First Amendment values no matter how germane the purpose is alleged to be. Taken together, the Court's failure to require prior consent, to understand that freedom of speech issues are at stake even when challenged expenditures are alleged to have a germane purpose, and to address workers' freedom of association interest give rise to a truncated calculus that appears to dispute Madison's view requiring consent before the ideological burdens of membership can attach. The Hudson rulerequiring dissenters to object as opposed to requiring unions to first obtain consent-ought to be contestable for several reasons. Given information

340. Davenport, $127 \mathrm{~S}$. Ct. at 2377.

341. Id. (citing Abood v. Detroit Bd. of Educ., 431 U.S. 209, 235-36 (1977) for the proposition that public-sector unions are only prohibited from using the fees of objecting nonmembers for ideological purposes that are not germane to the union's collectivebargaining duties). 
disparities and transaction cost imbalances that favor unions rather than individual dissenters, the rule requiring an affirmative objection by nonmembers in order to escape the burden of disallowable expenditures seems harsh-particularly since the Court has admitted such expenditure (as we have already seen) cannot be justified under its own free-rider premises. ${ }^{342}$ This approach appears astonishing given the Court's apparent acceptance of two lower courts' analyses that demonstrated the following: (A) in Beck, the court found that nearly eighty percent of union dues were not chargeable and (B) in Lehnert, the court found that the union spent nearly ninety percent of its dues revenue on non-representational activity. ${ }^{343}$ Confirmatory evidence seems to be widely available. ${ }^{344}$ While the Supreme Court is not required to draw factual inference from prior cases or congressional testimony, it is possible for perceptive observers to question the Court's insistence that dissenters dispute expenditure figures that ought to be promptly available to honest union officials.

It is possible, of course, that dissenters have a disguised preference for union political and ideological advocacy and have simply engaged in an attempt to escape financial contributions. But in the absence of such disguised preferences, it is axiomatic that the free-rider justification for union political and ideological expenditures collapses. ${ }^{345}$ Taken together, this analysis clarified by John Nowak and Ronald Rotunda's observations, implicates the following question: May a union, consistent with workers' rights of freedom of association and speech, use union dues to advance causes or interests not favored by all of the dues payers? ${ }^{346}$ The Supreme Court gives a negative answer to this question. ${ }^{347}$ Hence, it is difficult to justify the Hudson rule mandating that dissenters acquire sufficient

342. NowaK \& ROTUNDA, supra note 141 , at 1299 n.44. See also, Abood, 431 U.S. at 225-26 (holding that the state may require a public worker to pay dues or a service fee equal to dues "insofar as the [money] . . . is used to finance expenditures by the Union for the purposes of collective bargaining, contract administration, and grievance adjustment" but not for purposes of expressing political views).

343. HUNTER, KERSEY \& MilLER, supra note 2, at 4-15 (basing that figure on a detailed examination of union financial records the lower courts found evidence supporting the contention that non-germane expenditures were substantially higher than collectivebargaining related expenditures).

344. See Edith Hakola \& Rex Reed, Labor Plays Politics with Its Members' Dues, WASH. POST, Sept. 1, 1996, at C4 (noting unions tend to consume up to $80 \%$ of union dues on what can be seen as indirect political, ideological and other challengeable expenditures that seem unlikely to have a representational purpose) (cited in CHAVEZ \& GRAY, supra note 31, at 237); see also Compelled Political Speech: Hearing Before the S. Comm. on Rules \& Admin., 106th Cong. (2000) (statement of Leo Troy, Professor of Economics, Rutgers University), available at $\mathrm{http}: / /$ rules.senate.gov/hearings/2000/041200troy.htm.

345. Hutchison, $A$ Clearing in the Forest, supra note 3, at 1374.

346. NOWAK \& RoTUNDA, supra note 141, at 1299-1300.

347. See Abood, 431 U.S. at 225-26 (precluding a public sector union from charging dissenters in order to fund the expression of the union's political views). 
information and then act to prevent the extraction of dues for disallowable purposes when a simple rule requiring meaningful consent before extraction could resolve the problem. A rule that mandates prior consent by objectors, coupled with accounting safeguards that protect vulnerable workers who have limited access to information about union accounts and union efforts to conceal information, ${ }^{348}$ would maximize First Amendment protection for dues objectors.

The failure to mandate consent, the calcification of free-riding jurisprudence, and the Court's inadequate understanding of coercion is bolstered by the prospect that unions and the labor movement itself have been captured by hierarchs and their ideological allies, leaving workers little scope to object. Consistent with that probability, "union elections provide members with little real control over leaders" and unions are "inherently undemocratic." "The law has failed to require, let alone enforce, democratic collective-bargaining [and] has left union members subject to manipulation of union leaders ... with interests sharply different from theirs." 350 Unrestrained by rank and file members and driven by political ambition, union leaders have shifted labor organizations beyond the parameters of collective-bargaining. Union hierarchs maintain that "the only way to start winning [political] elections ... [is] to organize.,"351 Despite the Supreme Court's free rider analysis that disallows organizing expenses, labor unions have found relief in the Ninth Circuit's analysis justifying these same expenditures on the grounds of the purported need to strengthen unions. If union leaders are credible about their ideological aspirations, exceptional acuity is not required to understand that all contested expenditures (including organizing) are an extension of their politics despite the Supreme Court's rejection of a similar contention in Abood. ${ }^{352}$ Given this calculus favoring hierarchy, it is doubtful that minority interest (political or economic) will be placed at the top of the union's agenda. ${ }^{353}$ On the contrary, union leaders are likely to fund social and ideological positions as well as political candidates that share their own preferences. ${ }^{354}$ Since labor unions occupy seven of the top ten spots on a

348. See e.g., Seidemann v. Bowen, 499 F.3d 119 (2d Cir. 2007) (reversing summary judgment and directing the district court to consider whether the union improperly concealed and mischaracterized ideological and political expenditures).

349. Schwab, supra note 105 , at $369,370$.

350. Id. at 371 .

351. Jill Lawrence, Democrats Ponder Labor Split's Political Effect, USA TODAY, July 27,2005 , at $4 \mathrm{~A}$.

352. See Abood, 431 U.S. at 226 (discussing dues objectors who claimed that publicsector collective-bargaining is inherently political).

353. Hutchison, A Clearing in the Forest, supra note 3, at 1393.

354. Id. 
recent list of America's leading contributors to political parties, ${ }^{355}$ they evidently have the ability to do so. This conclusion gains greater force because public and private sector unions and their respective revenues cannot be clearly divided since they are often both affiliate members of, and contribute to, the same national labor organization and share the same mission. ${ }^{356}$ Separating public sector from private sector bargaining units is also difficult because approximately one-half of a typical union's financial activity occurs at the national level. ${ }^{357}$ As labor's "fortunes have faded in the marketplace, unions have directed their attention to political solutions. The growing influence of public sector unions, with their disdain for markets and natural reliance on political action, has fueled the shift." ${ }^{358}$ It is likely that only credulous observers suppose that unions devote their vast resources solely to promote political issues crucial to working people. ${ }^{359}$

No longer focused on the narrow economic interest of workers, freed from control by the membership, captivated by the preferences of society's elites, and emancipated from the necessity of sharing in workers' economic pain, ${ }^{360}$ unions have been liberated to achieve other objectives. An inspection of the evidence provided by Professor Troy, a careful survey of labor union websites, a detailed inspection of available union accounts, ${ }^{361}$ and an examination of the pronouncements of John Sweeney, Dennis Rivera and other labor leaders, reveals that the union movement has transformed itself into an anti-market fighting force for social justice. Facing a persistent decline in overall union membership, animated by the possibilities associated with special-interest politics and enthralled by an anti-market ideology, unions seem to have engaged in an effort to enforce the enlistment of all workers into a fighting force. This approach appears to foster the instrumentalization of every aspect of a worker's life in the

355. Lawrence, supra note 351 , at $4 \mathrm{~A}$.

356. See e.g., AFL-CIO/NEA Labor Solidarity Partnership, http://www.aflcio.org/aboutus/jointheaflcio/nea.cfm (last visited Aug. 4, 2007); Unions of the AFL-CIO, http://www.afl-cio.org/aboutus/unions (last visited Aug. 4, 2007) (providing a list of more than 50 public- and private-sector affiliate unions); see also CHAVEZ \& GRAY, supra note 31, at 15-17; Hutchison, A Clearing in the Forest, supra note 3, at 1315.

357. Marick F. Masters and Robert S. Atkin, Financial and Political Resources of Nine Major Public Sector Unions in the 1980s, 17 J. OF LAB. RES. 183, 186 (1996).

358. Hurd, supra note 24, at 305-06 (discussing Leo Troy's view). See also, ChAVEZ \& GRAY, supra note 31, at 17-21 (cataloguing labor's move to the left).

359. CHAVEZ \& GRAY, supra note 31 , at 18 (demonstrating "that union bosses have put their billions of dollars in compulsory dues behind" a number of proposals unrelated to the economic interests of workers).

360. See, e.g., Wilkinson \& French, supra note 96 (arguing that during the toughest economic times for organized labor in decades, union leaders are more likely to keep their jobs and get raises than the members they claim to serve. This contributes to a widening pay gap between union members and leaders).

361. See generally, CHAVEZ \& GRAY, supra note 31 , at 23-52. 
service of society, ${ }^{362}$ and thus moves the country toward transformation. ${ }^{363}$ This maneuver indicates that unions, at last, "have succumbed to what Jacques Ellul, the eccentric French Reformed thinker, prophesied in the 1960 s - the politicization of all aspects of life. ${ }^{364}$ This perspective breathes life into dues objectors' contention that public-sector bargaining itself is inherently political. ${ }^{365}$ Although this claim was rejected by the Supreme Court, objective observers may have a basis for extending this allegation to bargaining efforts in all sectors.

Union dues thus come into view as a prolepsis-the present anticipation - of enforced ideological conformity. Labor union dues are part of an ongoing struggle between incompatible views and incommensurable values. Empirical data confirms that unions, as participants in this struggle, face the risk of a loss of workplace influence. In the long-run, political power is sure to follow. Evidently, the rules of judicial construction do not prevent courts from taking note of such depressing facts. If courts believe that the nation requires healthy unions, and that strengthening the labor movement secures both the nation and the economy, there is little reason to believe that the aspirations of America's diverse workforce can vitiate the courts' conclusions. Strengthening labor unions, so the argument goes, redounds to the benefit of all workers including workers who are not yet represented by a labor union. This move may allow all challenged expenditures to be linked to the objective of strengthening labor unions and expanding membership as part of a potent force for transformative unionism. ${ }^{366}$ If this objective serves as a valid goal, doubtlessly courts are capable of discovering this "necessity." It is impossible to believe that courts, unconstrained by an energetic conception of freedom of speech, conscience, and association, will snub the labor movement's ambition to convert "necessity" into a representational, and therefore chargeable, activity. The logic of necessity, in the competent hands of courts, could extend to plainly political and ideological activities. This occurrence is particularly plausible because the Supreme Court has held, in Hanson, that mandating "financial support of the collectivebargaining agency by all who receive the benefits of its work . . . does not violate the First [Amendment]." ${ }^{367}$ Political and ideological activities appear to fit within the Court's rather expansive framework.

362. Harry G. Hutchison, What Workers Want or What Labor Experts Want Them to Want? 26 QLR (forthcoming 2008) [hereinafter, Hutchison, What Workers Want] (manuscript on file with author).

363. Hutchison, What Workers Want, supra note 362.

364. Charles Colson, Promises, Promises: How to Really Build a 'Great Society', Christianity TODAY, Aug. 2007, at 64.

365. Abood v. Detroit Bd. of Educ., 431 U.S. 209, 226 (1977).

366. Hutchison, A Clearing in the Forest, supra note 3, at 1370.

367. Ry. Employes' Dep't v. Hanson, 35I U.S. 225, 238 (1956). 
The Davenport Court complements Hanson's language by subordinating dues objections to the following proposition: Public-sector unions are only prohibited from using the fees of objecting nonmembers for ideological purposes that are not germane to the union's collectivebargaining duties. ${ }^{368}$ The Court evidently failed to preclude what union hierarchs appear to find desirable: the metamorphosis of the ideological into the economic. In a post-enlightenment world, it is probable that language can be found that instantiates self-interested economic benefits within an ideological and political framework even though workers are bound to disagree with such claims. Less than skeptical free-rider analysis combined with a highly contingent interpretation of the First Amendment and bolstered by the failure to require consent, permits the conversion of formerly nongermane activities into germane and, therefore, chargeable ones.

Dues objectors have often alleged that sums extracted under agencyfee agreements "have been and are and will be regularly and continually used by the ... unions to carry on finance and pay for political activities directly at cross-purposes with the free will and choice" of workers. ${ }^{369}$ Resolving this squabble has proved difficult. As a result, dues objectors have sought freedom in paycheck protection referenda and legislation. Such initiatives inevitably become the source of litigation. Properly understood, the Davenport case provides little positive news to dues objectors who wish to protect their individual sovereignty and autonomy through referenda. Although the Supreme Court rightly enforced $\S 760$, the Court's corresponding reification of doubtful precedent provides latitude for courts and unions to avoid the substantive implications of the First Amendment. This calculus places dues objectors' freedom of association and free speech claims at risk and situates constitutional values astride a fragile pedestal. It is unlikely that Washington State's paycheck protection restriction can reclaim First Amendment rights. This forecast is applicable to similar efforts in other states. Dues objectors who wish to move beyond negligibility and toward substantive protection of freedom of speech and association rights are likely to discover that shelter can only be found in right-to-work legislation that renews the vitality of individual consent and autonomy, and which clearly and unmistakably rejects compulsory union membership in the form of coerced financial contributions. But, even so, given Supreme Court precedent, ${ }^{370}$ they should be wary of adjudication that

368. Davenport v. Wash. Educ. Ass'n., 127 S. Ct. 2372, 2377 (2007) (citing Abood, 431 U.S. at 235-36).

369. Bhd. of Ry. Clerks v. Allen, 373 U.S. 113, 118 (1963).

370. See, e.g., Hanson, 351 U.S. at 232 (holding that the 1951 amendment to the RLA permits the negotiation of union shop agreements notwithstanding any law of any state). 
has the potential to vindicate Stanley Fish's less than hopeful assessment of the authority of First Amendment freedoms in modern liberal societies.

Taken together, these doubts intimate that in a putatively liberal society such as ours, contemporary liberalism may be deeply paradoxical at its core. ${ }^{371}$ As Larry Alexander shows, "the freedoms that are emblematic of liberalism - the freedoms of expression, religion, and association-all appear to require a governmental stance of evaluative neutrality.",372 Thus, freedom of expression and freedom of religion reserved only for people with whom the government agrees are neither freedom of expression nor freedom of religion. ${ }^{373}$ Similarly, freedom of expression that is only reserved for people with whom union hierarchs, empowered by government coercion, agree is unlikely to constitute freedom of expression or be consistent with evaluative neutrality. This paradigm raises a final question: Can union dues objectors ever overcome the emerging tendency of modern liberalism to suppress, not vindicate, First Amendment claims?

\section{CONCLUSION}

Historically, many policy innovations reflect the judgment that social science and bureaucratic regulation have much to offer society. One of the policy innovations arising out of the period that began during the 1930's was society's resort to the shibboleth that industrial peace, stability and economic adjustment would spring forth from bureaucratic managerialism. ${ }^{374}$ This endeavor to deliver economic freedom to workers reified bargaining statutes, but issued forth in a paradox in which workers are required to give up a portion of their freedom to union hierarchs and government administrative agencies in exchange for the hope of higher wages, greater job security, and collective freedom. This approach operates as a social scientific process in which the terms of employment as well as the conditions under which labor unions materialize are regulated by a hierarchy. The consequence is a legal edifice of stunning complexity $^{375}$ and doubtful efficacy. ${ }^{376}$

371. AleXANDER, IS THERE A Right OF FREEDOM OF EXPRESSION?, supra note 55, at 148.

372. Id.

373. Id.

374. See e.g., Stanley D. Henderson, Labor law: Cases and Comment 40-43 (2005).

375. United Food \& Commercial Workers Union, Local 1036 v. NLRB, 307 F.3d 760, 763 (9th Cir. 2002) (en banc) ("Establish[ing] an elaborate and complicated structure that governs labor relations in almost all of the industries within the nation's private sector.").

376. See, e.g., RICHARD VEDDER \& LOWELl GallawAY, OUT OF WORK: UNEMPLOYMENT AND GOVERNMENT IN TWENTIETH-CENTURY AMERICA (1993) (showing how pro-labor laws enacted during the 1930's contributed to unemployment, increasing differential between black and white workers unemployment, and worsened the economic recovery based on the 
The odds of capture, the rise in the union politicization and the absence of preference and interest uniformity ensure that not all workers represented by a union will be treated equally, which leads to an internal conflict between and among workers. Metaphorically, Harvey Mansfield argues that in our democracy, politics are "motivated especially by the sense that you are not being treated equally."377 Union political decisionmaking as an internal governance matter-either hierarchal or majoritarian-provides ample opportunities to subordinate the interests and preferences of dissenters. This move conduces to an increasing sense of grievance, which core First Amendment values, energetically enforced, might reclaim.

Despite that possibility, America's current contentious environment implies that the nature and defensibility of mutual obligations, including the obligation to pay union dues, have become unclear. This possibility interacts with another: Postmodernism, even if only partially embraced, may leave society, the legislature, and the courts without the vocabulary that is necessary to convincingly combat such moves. If true, adjudication of First Amendment disputes before the U.S. Supreme Court or other courts is more likely to become a diversion rather than a device that reclaims any rights for dissenting workers. At the same time, suppression of viewpoint diversity will likely be explained in benign terms. Yet, however benign the explanation may be, those singled out for disfavor by union officials and those who are unable to find shelter in adjudication by the NLRB, the state, or Federal courts can be forgiven for suspecting more invidious forces are at work. ${ }^{378}$

credulous belief that high wages and high prices would eliminate the recession and bring industrial peace).

377. Harvey Mansfield, How to Understand Politics, FirST ThINGS, Aug./Sept. 2007, at 42 (linking this move in part to postmodern identity politics).

378. My debt to Justice Scalia should be obvious. See Locke v. Davey, 540 U.S. 712, 733 (2004) (Scalia, J., dissenting). 